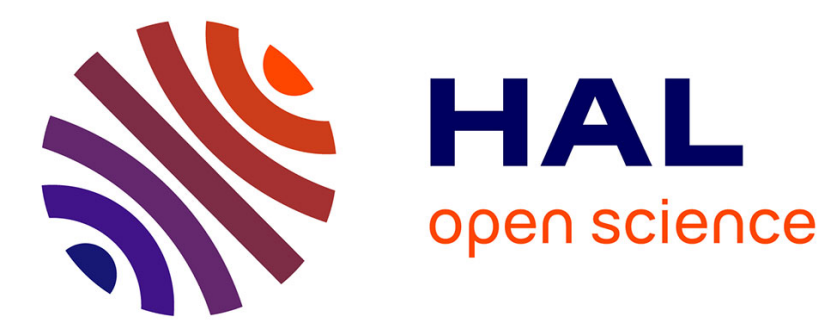

\title{
Comparison of stabilization by Vitamin E and 2,6-di-tert-butylphenols during polyethylene radio-thermal-oxidation
}

Emmanuel Richaud

\section{- To cite this version:}

Emmanuel Richaud. Comparison of stabilization by Vitamin E and 2,6-di-tert-butylphenols during polyethylene radio-thermal-oxidation. Radiation Physics and Chemistry, 2014, 103, pp.158-166. 10.1016/j.radphyschem.2014.05.053 . hal-01024442

\section{HAL Id: hal-01024442 \\ https://hal.science/hal-01024442}

Submitted on 16 Jul 2014

HAL is a multi-disciplinary open access archive for the deposit and dissemination of scientific research documents, whether they are published or not. The documents may come from teaching and research institutions in France or abroad, or from public or private research centers.
L'archive ouverte pluridisciplinaire HAL, est destinée au dépôt et à la diffusion de documents scientifiques de niveau recherche, publiés ou non, émanant des établissements d'enseignement et de recherche français ou étrangers, des laboratoires publics ou privés. 


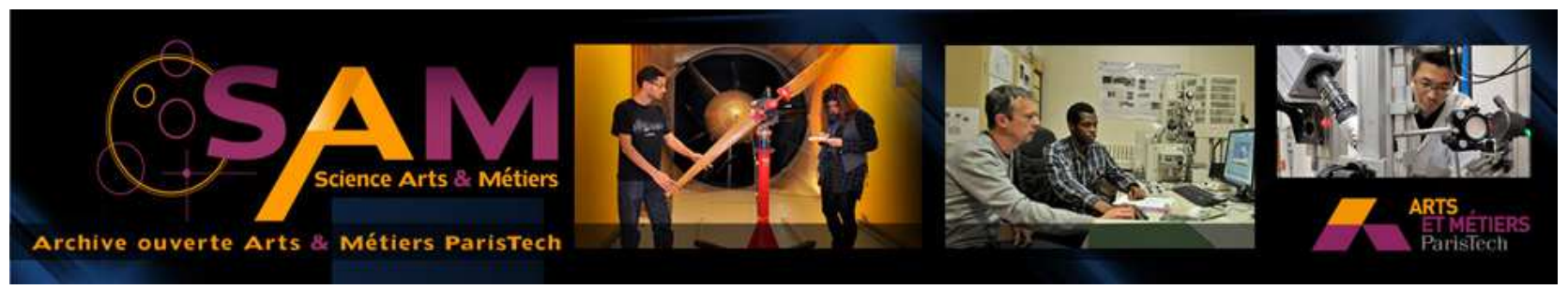

Science Arts \& Métiers (SAM)

is an open access repository that collects the work of Arts et Métiers ParisTech researchers and makes it freely available over the web where possible.

This is an author-deposited version published in: http://sam.ensam.eu

Handle ID: .http://hdl.handle.net/10985/8345

\section{To cite this version :}

Emmanuel RICHAUD - Comparison of stabilization by Vitamin E and 2,6-di-tert-butylphenols during polyethylene radio-thermal-oxidation - Radiation Physics and Chemistry - Vol. 103, p.158$166-2014$ 
By Emmanuel RICHAUD*

Arts et Métiers ParisTech, CNRS, PIMM UMR 8006, 151 bd de l'Hôpital, 75013 Paris, France

* corresponding author : emmanuel.richaud@ensam.eu

\section{KEYWORDS}

Polyethylene, radio-thermal oxidation, vitamin $\mathrm{E}$, phenolic antioxidants, kinetic analysis.

\section{ABSTRACT}

This paper reports a compilation of data for PE + vitamin E and 2,6-di-tert-butyl phenols oxidation in radio-thermal ageing. Data unambiguously show that vitamin $\mathrm{E}$ react with $\mathrm{P}^{\circ}$ and $\mathrm{POO}{ }^{\circ}$ whereas $2,6-$ di-tert-butyl phenols only react with $\mathrm{POO}^{\circ}$. Kinetic parameters of the stabilization reactions for both kinds of antioxidants were tentatively extracted from phenol depletion curves, and discussed regarding the structure of the stabilizer. They were also used for completing an existing kinetic model used for predicting the stabilization by antioxidants. This one permits to compare the efficiency of stabilizer with dose rate or sample thickness. 


\section{INTRODUCTION}

Unstabilized polyolefins oxidation proceeds by an in chain radical mechanism characterized by an initially long chain kinetic length, meaning that propagation reactions

$\mathrm{P}^{\circ}+\mathrm{O}_{2} \rightarrow \mathrm{POO}^{\circ} \quad \mathrm{k}_{2}$

$\mathrm{POO}^{\circ}+\mathrm{PH} \rightarrow \mathrm{POOH}+\mathrm{P}^{\circ} \quad \mathrm{k}_{3}$

predominate over termination. Oxidation can be retarded if stabilizers compete with propagation. Due to their $\mathrm{O}-\mathrm{H}$ bond weaker than polyethylene $\mathrm{C}-\mathrm{H}$ one, phenols show the requested features:

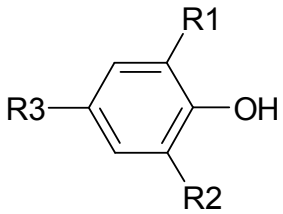

Despite it is non-reactive, the R3- group influences the physical aspects of stabilization: solubility (Billingham et al., 1991), diffusion (Al-Malaika, 1991), evaporation (Calvert and Billingham, 1979)...

2,6-di-tert-butyl-phenols are the most current family of antioxidants for polyolefins (Schwarzenbach et al., 2001). They react by donating a hydrogen atom to a chain carrying peroxy radical. The resulting phenoxyl radical $A^{\circ}$ isomerizes, and then reacts with another peroxyl or with $\mathrm{O}_{2}$, with another phenoxyl by dismutation or coupling, or generate a new form of stabilizer (Allen et al., 1985; Pospíšil et al., 1991; Pospíšil, 1993; Pospišil et al., 1996; Pospíšil et al., 2002). These mechanisms can be represented by a "kinetically equivalent" scheme (Richaud et al., 2011; Richaud, 2013) using a limited number of adjustable parameters:

$\begin{array}{ll}\mathrm{POO}^{\circ}+\mathrm{AH} \rightarrow \mathrm{POOH}+\mathrm{A}^{\circ} & \mathrm{k}_{\mathrm{S} 1} \\ \mathrm{POO}^{\circ}+\mathrm{A}^{\circ} \rightarrow \mathrm{POO}-\mathrm{A} & \mathrm{k}_{\mathrm{S} 2}\end{array}$

Which simulates the main features of stabilization by phenols in polyolefins: linear increase of the induction period with initial phenol concentration, negligible changes on the maximal oxidation rate i.e. steady state characteristics, and stabilizer depletion during thermal oxidation. 
Vitamin $\mathrm{E}$ ( $\alpha$-tocopherol) is another phenol having anti-inflammatory action (Tahan et al. 2011, Reiter et al., 2007). Its structure

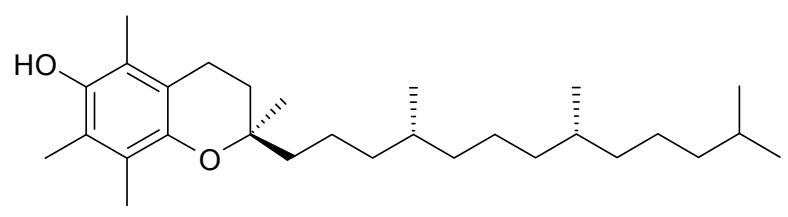

is close of phenolic antioxidants. However, there are two specificities:

- Methyl substituent in 2 and 6 positions instead of tert-butyl.

- A linear aliphatic chain favoring its solubility in lipids, and a low molar mass increasing its diffusivity.

Vitamin E was shown to stabilize UHMWPE during the post irradiation exposure, with slower build-up of ketones, hydroperoxides (Costa et al., 2009; Mallégol et al., 2001a) and a decrease of the concentration of intermediary unstable radicals (Jahan and Walters, 2011). In the case of squalane oxidation monitored by Oxidation Induction Time (OIT) at $200^{\circ} \mathrm{C}$ (Breese et al., 2000), the changes of OIT with phenol concentration were shown to be greater for vitamin E than for AO1 and AO2 (see APPENDIX A for structure). The lower molar mass (and so high volatility) of AO2 explains why it is less efficient than AO1. However, vitamin E is strongly more efficient than AO1 despite its molar mass two times lower than AO1. Al-Malaika and Peng (2008) compared the melt stabilization of a LLDPE with $900 \mathrm{ppm} \mathrm{AO3} \mathrm{(ca} 16.1 \times 10^{-4} \mathrm{~mol} \mathrm{I}^{-1}$ in molten polymer) and $300 \mathrm{ppm}$ vitamin $\mathrm{E}$ (ca $6.6 \times 10^{-4} \mathrm{~mol} \mathrm{I}^{-}$ ${ }^{1}$ ) and observed a very close behavior, suggesting that vitamin $E$ is more efficient than a hindered phenol of comparable structure even at a lower concentration.

Even if several by-products were evidenced in thermally degraded PE by Al-Malaika et al. (2001), its stabilization mechanism is expected to have some commonality with other 2,6-di-tert-butyl phenols (Mallégol et al., 2001b; Lucarini and Pedulli, 2007): 

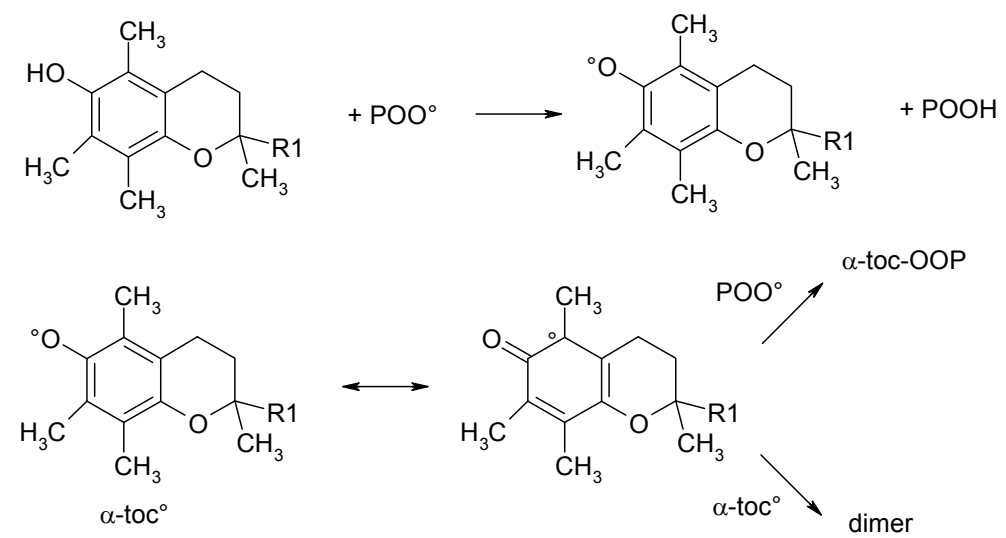

Some authors have compared AO differing by R1, R2 and R3 group and addressed the influence of electro-attractive effects on the antioxidant properties (Amorati et al., 2006, Amorati et al., 2007). Basing on the assumption that vitamin E and 2,6-di-tert-butyl phenols have the same stabilization mechanism, Lucarini and Pedulli (2007) have compiled rate constants for the reaction between POO ${ }^{\circ}$ and phenols and observed that:

$$
\mathrm{k}_{\text {inh }}\left(\alpha, \beta, \gamma, \delta \text { tocopherol) }>>\mathrm{k}_{\text {inh }}(\mathrm{AO} 2)\right.
$$

However, they also reported very comparable bond dissociation energies values for the $\mathrm{O}-\mathrm{H}$ group of phenol, which is in contradiction with the observed difference between rate constants of the reaction towards $\mathrm{POO}^{\circ}$ radicals (more than 2 decades). Is it due to the method of radical generation (AIBN initiated oxidation), or the hypothesis made on vitamin $\mathrm{E}$ stabilization, or the method for solving the kinetic scheme of the oxidation (analytical instead of numerical)?

This paper is hence aimed at explaining those results by using the kinetic analysis as a comprehensive tool, and draw conclusions on the effect of ortho substituents on the kinetics of stabilization by:

- reviewing literature to derive a mechanistic scheme for vitamin E stabilization in PE and calculating kinetic parameters under several ratio-thermal conditions.

- comparing the implications of differences between vitamin $E$ and other sorts of hindered phenols, so as to link the nature of aromatic group substituent with phenol rate constants of stabilization.

- use kinetic model to clarify the radio-thermal-oxidation for PE stabilized with each sort of phenols. 


\section{RESULTS AND DISCUSSION}

1. Kinetic modeling of stabilization by Vitamin $E$

According to the mechanism proposed in (Mallégol et al., 2001b; Lucarini and Pedulli, 2007) and used in (Amorati et al., 2006, Amorati et al., 2007), vitamin E would not react when polymer is aged in inert atmosphere, typically during the UHMWPE sterilization by $\gamma$ radiation. It is in contradiction with results obtained by Costa et al. (2009) according to which vitamin E is consumed when polymer is irradiated under nitrogen. The initial rate of stabilizer depletion is ca $2.3 \times 10^{-4} \mathrm{~mol} \mathrm{I}^{-1} \mathrm{kGy}^{-1}$ under inert atmosphere instead of $1.6 \times 10^{-4} \mathrm{~mol} \mathrm{l}^{-1} \mathrm{kGy}^{-1}$ under air (i.e. paradoxically lower than under nitrogen). Vitamin E stabilization scheme could be more complex 2,6-di-tert-butyl-phenols one. It could be:

$\begin{array}{lc}\mathrm{VitE}+\mathrm{POO}^{\circ} \rightarrow \mathrm{POOH}+\mathrm{VitE}^{\circ} & \mathrm{k}_{\mathrm{S} 1} \\ \mathrm{VitE}^{\circ}+\mathrm{POO}^{\circ} \rightarrow \text { inactive product } & \mathrm{k}_{\mathrm{S} 2} \\ \mathrm{VitE}+\mathrm{P}^{\circ} \rightarrow \mathrm{VitE}^{\circ} & \mathrm{k}_{\mathrm{S} 3} \\ \mathrm{VitE}^{\circ}+\mathrm{P}^{\circ} \rightarrow \text { inactive product } & \mathrm{k}_{\mathrm{S} 4}\end{array}$

In UHMWPE films thin enough (such those used in Costa et al. (2009) to neglect all diffusion phenomena, $\mathrm{k}_{\mathrm{S} 1 \ldots} \mathrm{k}_{\mathrm{S} 4}$ can be estimated "simply" by an inverse approach from ageing experiments (Richaud et al., 2008; Richaud et al., 2011; Richaud, 2013). For that purpose, Vitamin E stabilization reactions are added to the scheme previously established for additive free PE (Khelidj et al., 2006) valid at any irradiation dose rate and temperature:

$$
\begin{array}{ll}
\mathrm{PH}+\mathrm{h} v \rightarrow \mathrm{P}^{\circ}+1 / 2 \mathrm{H}_{2} & \mathrm{r}_{\mathrm{i}}=10^{-7} \times \mathrm{G}\left(\mathrm{P}^{\circ}\right) \times \mathrm{I} \\
\mathrm{POOH} \rightarrow 2 \mathrm{P}^{\circ}+\gamma_{1} \mathrm{P}=\mathrm{O}+\gamma_{2} \mathrm{~S} & \mathrm{k}_{1 \mathrm{u}} \\
\mathrm{POOH}+\mathrm{POOH} \rightarrow \mathrm{P}^{\circ}+\mathrm{POO}^{\circ}+\gamma_{1} \mathrm{P}=\mathrm{O}+\gamma_{2} \mathrm{~S} & \mathrm{k}_{1 \mathrm{~b}}
\end{array}
$$




$$
\begin{array}{lc}
\mathrm{P}^{\circ}+\mathrm{O}_{2} \rightarrow \mathrm{POO}^{\circ} & \mathrm{k}_{2} \\
\mathrm{POO}+\mathrm{PH} \rightarrow \mathrm{POOH}+\mathrm{P}^{\circ} & \mathrm{k}_{3} \\
\mathrm{P}^{\circ}+\mathrm{P}^{\circ} \rightarrow \gamma_{4} \text { crosslink }+\left(1-\gamma_{4}\right)>\mathrm{C}=\mathrm{C}< & \mathrm{k}_{4} \\
\mathrm{P}^{\circ}+\mathrm{POO}^{\circ} \rightarrow\left(1-\gamma_{5}\right) \text { crosslink }+\gamma_{5} \mathrm{POOH}+\gamma_{5}>\mathrm{C}=\mathrm{C}< & \mathrm{k}_{5} \\
\mathrm{POO}^{\circ}+\mathrm{POO}^{\circ} \rightarrow\left(\mathrm{PO}{ }^{\circ} \mathrm{OP}\right)_{\text {cage }}+\mathrm{O}_{2} & \mathrm{k}_{60} \\
\left(\mathrm{PO}^{\circ} \mathrm{OP}\right)_{\text {cage }} \rightarrow \mathrm{POOP} & \mathrm{k}_{61} \\
\left(\mathrm{PO}{ }^{\circ} \mathrm{OP}\right)_{\text {cage }} \rightarrow \mathrm{POH}+\mathrm{P}=\mathrm{O} & \mathrm{k}_{62} \\
\left(\mathrm{PO}{ }^{\circ} \mathrm{OP}\right)_{\text {cage }} \rightarrow 2 \mathrm{P}^{\circ}+2 \gamma_{1} \mathrm{P}=\mathrm{O}+2 \gamma_{2} \mathrm{~S} & \mathrm{k}_{63}
\end{array}
$$

For skipping a great part of the mathematics (published in Rincon Rubio et al., 2001; Khelidj et al., 2006; Richaud, 2013, see also Appendix B), it is just recalled that this mechanistic scheme is derived into a set of differential equations. This one is solved which gives changes in $\mathrm{P}^{\circ}, \mathrm{POO}^{\circ}, \mathrm{POOH}$, $\left(\mathrm{PO}{ }^{\circ} \mathrm{OP}\right)_{\text {cage }} \mathrm{AH}, \mathrm{A}^{\circ}$ concentrations in amorphous phase versus time, dose, and thickness in the case of bulk materials. The shape of stabilizer depletion curve allows in principle to determine in particular $\mathrm{k}_{\mathrm{s} 1}$ and $\mathrm{k}_{\mathrm{s} 3}$, since:

$$
\frac{d[A H]}{d t}=-k_{S 1}\left[P O O^{\circ}\right][A H]-k_{S 3}\left[P^{\circ}\right][A H]
$$

The following strategy was hence implemented:

- simulations of ageing under inert atmosphere are first used for determining $k_{53}$ and $k_{s_{4}}$, since in absence of oxygen, there is no $\mathrm{POO}^{\circ}$ reacting with vitamin $\mathrm{E}$, simulations are insensitive to $\mathrm{k}_{\mathrm{S} 1}$ and $\mathrm{k}_{\mathrm{S} 2}$. - simulations of ageing under air or in presence of oxygen are then used for determining $k_{\mathrm{s} 1}$ and $k_{\mathrm{s} 2}$. - given the simplicity of the shapes of kinetic curves, several sets of constants could theoretically fit. It was published (Richaud et al., 2011) that $\mathrm{k}_{\mathrm{s} 2}$ corresponds to a fast reaction involving two reactive radicals and its value has only a minor influence on the simulations provided it has a physical sense. $\mathrm{k}_{\mathrm{s} 2}$ was thus fixed from Denisov and Afanas'Ev (2005):

$$
\mathrm{k}_{\mathrm{s} 2}=5.10^{8} \mathrm{Imol}^{-1} \mathrm{~s}^{-1}
$$


The same assumption can be done for $\mathrm{k}_{\mathrm{s} 4}$ having in mind that $\mathrm{P}^{\circ}$ are more reactive than $\mathrm{POO}^{\circ}$ so:

$$
\mathrm{k}_{\mathrm{S} 4}=10^{9} \mathrm{I} \mathrm{mol}^{-1} \mathrm{~s}^{-1}>\mathrm{k}_{\mathrm{S} 2}
$$

Hence, $\mathrm{k}_{\mathrm{s} 3}$ becomes the only adjustable parameter for simulating results for vitamin $\mathrm{E}$ depletion during irradiation under inert atmosphere (Costa et al.; 2009). After an adjustment procedure (see Figure 1), $\mathrm{k}_{\mathrm{S} 3}$ was estimated ca $7.5 \times 10^{4} \mathrm{I} \mathrm{mol}^{-1} \mathrm{~s}^{-1}$ presumably at room temperature. $\mathrm{k}_{\mathrm{s} 1}$ remains thus the only adjustable parameter to be determined. Simulations of the results under air (Costa et al., 2009) with $\mathrm{k}_{\mathrm{s} 2}, \mathrm{k}_{\mathrm{s3}}$ and $\mathrm{k}_{\mathrm{s} 4}$ previously fixed are given in Figure $2 . \mathrm{k}_{\mathrm{s} 1}$ was estimated ca $450 \mathrm{I} \mathrm{mol}^{-1} \mathrm{~s}^{-1}$.

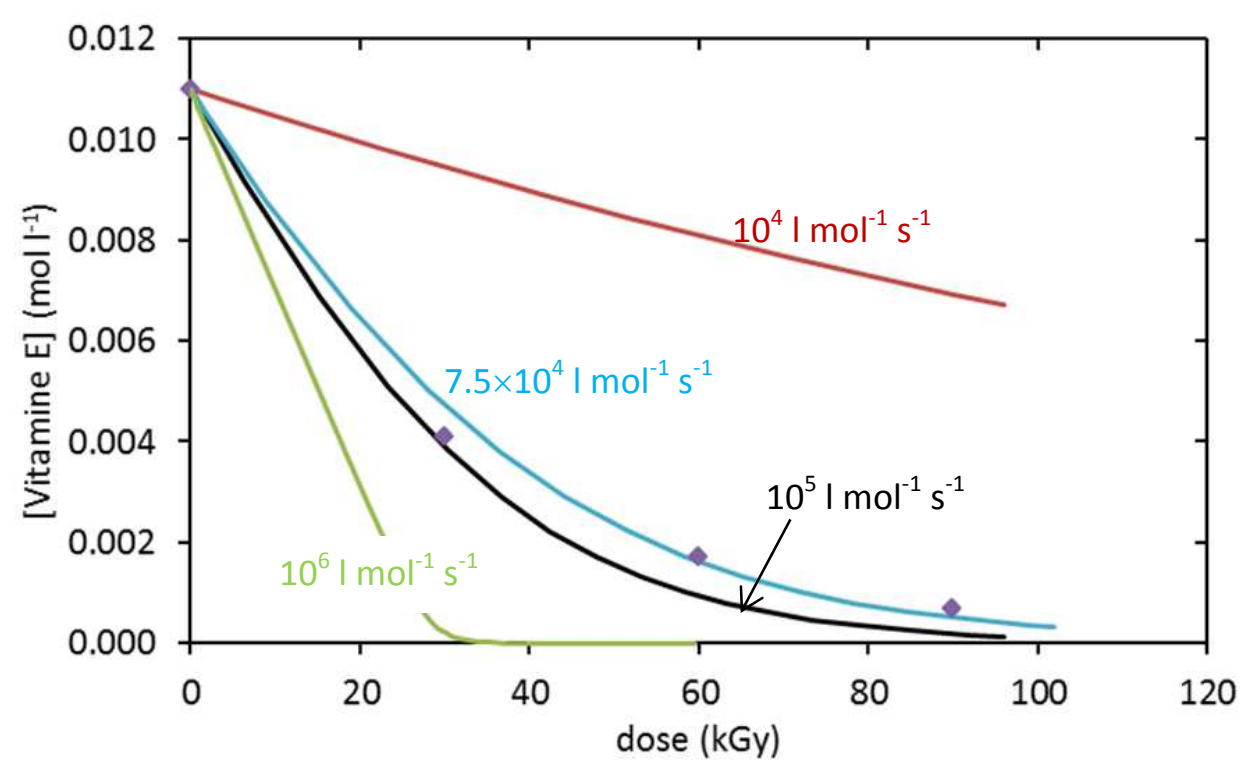

Figure 1. Kinetics of vitamin E depletion during $6 \mathrm{kGy} \mathrm{h}^{-1}$ irradiation under inert atmosphere at room temperature ( from Costa et al., 2009) and simulations by the model with several $\mathrm{k}_{\mathrm{s3}}$ values. 


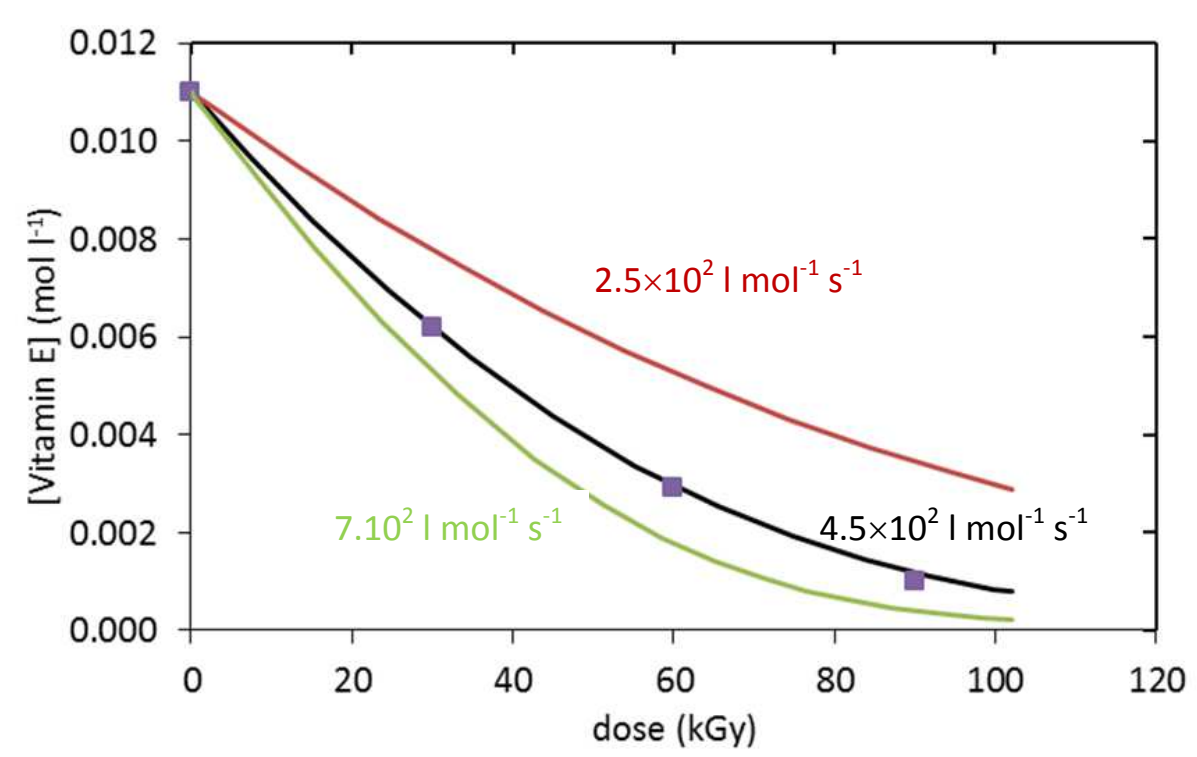

Figure 2. Kinetics of vitamin $\mathrm{E}$ depletion during $6 \mathrm{kGy} \mathrm{h}^{-1}$ irradiation under air at room temperature ( $\square$ from Costa et al., 2009) and simulations by the model with several $k_{s 1}$ values.

Those values allow to simulate other results obtained for irradiation under air (Bracco et al., 2007) for several other vitamin E initial concentration, supposing that irradiation conditions are the same than for (Costa et al., 2009).

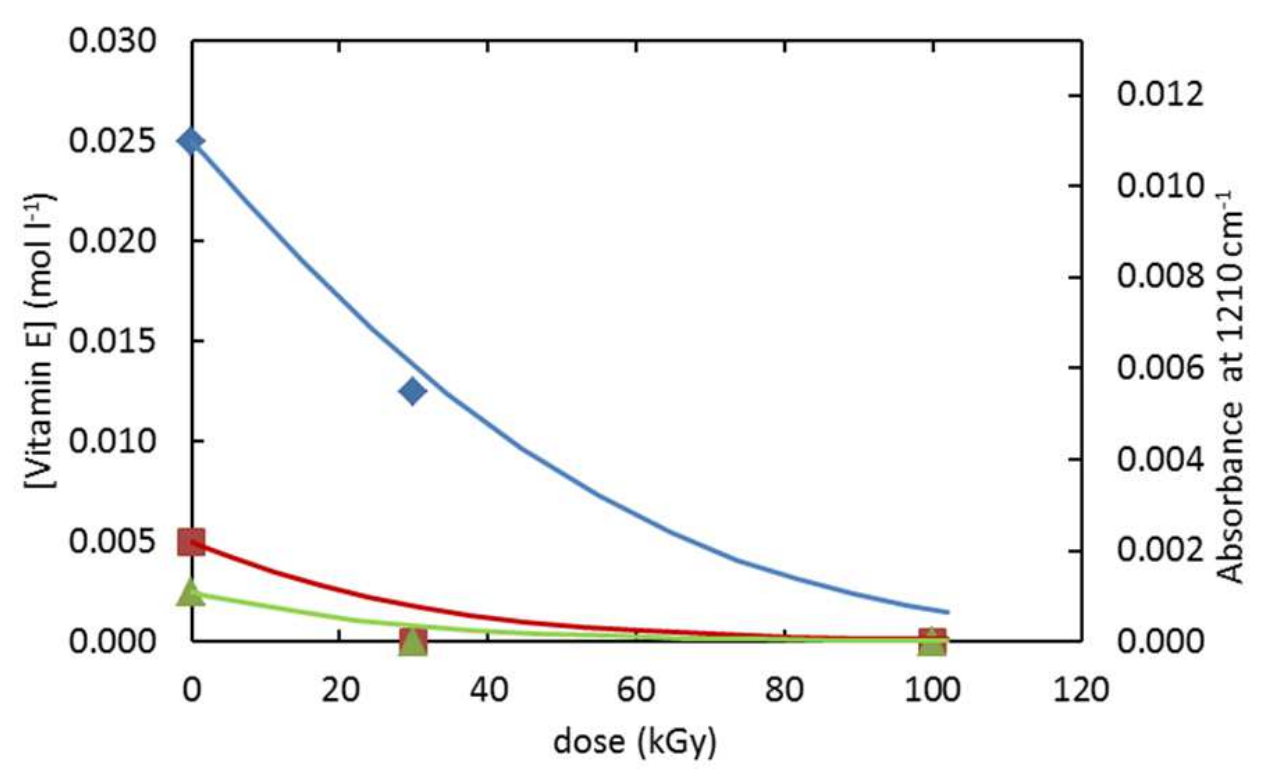

Figure 3. Kinetics of vitamin E depletion during $6 \mathrm{kGy} \mathrm{h}^{-1}$ irradiation under air at room temperature $\left(\bullet: 0.5 \%, \mathbf{\square}: 0.1 \%, \boldsymbol{\Delta}: 0.05 \%\right.$ from Bracco et al., 2007) and simulations by the model with $\mathrm{k}_{\mathrm{s} 1} \ldots \mathrm{k}_{\mathrm{s} 4}$ values given above. 
The relative contribution of stabilization reaction S1 and S2 vs S3 and S4 i.e. involving whether $\mathrm{POO}^{\circ}$ and $\mathrm{P}^{\circ}$ radicals can be discussed from simulations of vitamin $\mathrm{E}$ depletion curves with:

$-\mathrm{k}_{\mathrm{s} 1}=450, \mathrm{k}_{\mathrm{s} 2}=5.10^{8} \mathrm{I} \mathrm{mol}^{-1} \mathrm{~s}^{-1}, \mathrm{k}_{\mathrm{s} 3}=\mathrm{k}_{\mathrm{s} 4}=0$, which corresponds to an antioxidant reacting like classical 2,6-di-tert-butyl-hindered phenols.

$-\mathrm{k}_{\mathrm{s} 1}=450, \mathrm{k}_{\mathrm{s} 2}=5.10^{8}, \mathrm{k}_{\mathrm{s} 3}=7.5 \times 10^{4}, \mathrm{k}_{\mathrm{s} 4}=10^{9} \mathrm{I} \mathrm{mol}^{-1} \mathrm{~s}^{-1}$, corresponding to a possible set of rate constant for vitamin $\mathrm{E}$ (see Figures 1-3).

Indeed, it is known that irradiation induces a slight heating of sample: according to Costa et al. (2008), the actual temperature of a "room temperature" irradiation would be ca $60^{\circ} \mathrm{C}$. We have hence chosen to set at $60^{\circ} \mathrm{C}$ the temperature in the model runs to get more realistic values of time to reach $[\mathrm{AH}]=0$ (it does not change the conclusions drawn from Figure 4 and 5 however).

Those simulations were performed:

- in thin films for radio or thermal oxidation (Figure 4).

- in the depth of thick samples during a radiochemical ageing (Figure 5). Those simulations profiles were obtained by adding diffusional terms in the differential system and solving this latter in time and space for getting antioxidant $=\mathrm{f}$ (dose, thickness) in the $\mathrm{i}^{\text {th }}$ layer (Rincon-Rubio et al., 2001, see also Appendix B):

$$
\begin{gathered}
\frac{d[A H]}{d t}=-k_{S 1}\left[P O O^{\circ}\right][A H]-k_{S 3}\left[P^{\circ}\right][A H]+D_{A H} \cdot \frac{\partial^{2}[A H]}{\partial x^{2}} \\
\frac{d\left[O_{2}\right]}{d t}=-k_{2}\left[P^{\circ}\right]\left[O_{2}\right]+k_{60}\left[P O O^{\circ}\right]^{2}+D_{O 2} \cdot \frac{\partial^{2}\left[O_{2}\right]}{\partial x^{2}}
\end{gathered}
$$

Simulations in Figure 5 were performed at $60^{\circ} \mathrm{C}$ with:

- $\mathrm{D}_{\mathrm{O} 2}=8.10^{-7} \mathrm{~cm}^{2} \mathrm{~s}^{-1}$ (Van Krevelen and Te Nijenhuis, 2009),

- $D_{A H}=5.2 \times 10^{-9} \mathrm{~cm}^{2} \mathrm{~s}^{-1}$ (Oral et al., 2006). 
We also verified that even changes of $D_{A H}$ of one decade or more did not change the simulations, i.e. that characteristic time for diffusion $\left(\tau_{\text {diffusion }}=L^{2} / D_{A H}, L\right.$ being the sample thickness, was significantly greater than the irradiation time) was higher than characteristic time for reaction.

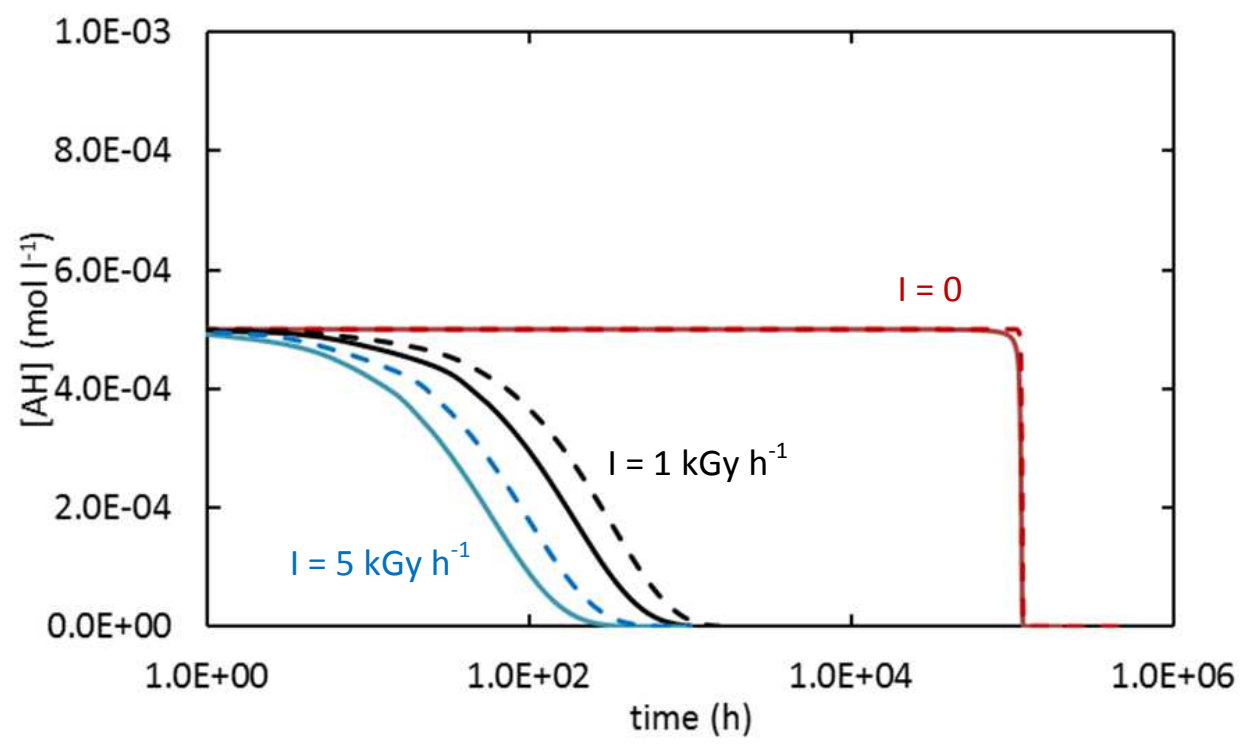

Figure 4. Influence of stabilization involving $\mathrm{P}^{\circ}$ reaction on phenol depletion for simulation with dose rate $\mathrm{I}=0,1$ or $5 \mathrm{kGy} \mathrm{h}^{-1}$ for $\mathrm{PE}+$ vitamin $\mathrm{E}$ (full line) or PE + 2,6-di-tert-butyl-phenol (dashed line).

Both Figure 4 and $5 a$ show that stabilization by $\mathrm{P}^{\circ}$ trapping (S3 and S4 reactions) is negligible compared to stabilization by $\mathrm{POO}^{\circ}$ trapping (S1 and S2) when oxygen is present (i.e. in films or superficial layers). Possible explanations are:

(1) $\mathrm{P}^{\circ}$ radicals are scavenged by $\mathrm{O}_{2}$ faster than they react with vitamin $\mathrm{E}: \mathrm{k}_{2}\left[\mathrm{O}_{2}\right]>\mathrm{k}_{\mathrm{S}_{3}}[\mathrm{AH}]$

(2) Vitamin $\mathrm{E}$ is more reactive towards $\mathrm{POO}^{\circ}$ than $\mathrm{P}^{\circ}: \mathrm{k}_{\mathrm{S} 1}\left[\mathrm{POO}^{\circ}\right]>\mathrm{k}_{\mathrm{S3}}\left[\mathrm{P}^{\circ}\right]$

In PE, oxygen solubility is: $\mathrm{s}_{\mathrm{O} 2} \sim 10^{-8} \mathrm{~mol} \mathrm{I}^{-1} \mathrm{~Pa}^{-1}$ (Van Krevelen and Te Nijenhuis, 2009)

so that, under air $\left(\mathrm{P}_{\mathrm{O} 2}=0.02 \mathrm{MPa}\right): \quad\left[\mathrm{O}_{2}\right]=\mathrm{s}_{\mathrm{O} 2} \times \mathrm{P}_{\mathrm{O} 2} \sim 10^{-4} \mathrm{moll}^{-1}$

so:

$$
\mathrm{k}_{2}\left[\mathrm{O}_{2}\right] \sim 10^{4} \mathrm{~s}^{-1}
$$

which is clearly higher than the product $\mathrm{k}_{\mathrm{S}_{3}}[\mathrm{AH}]$ with $\mathrm{k}_{\mathrm{S3}} \sim 10^{5} \mathrm{I} \mathrm{mol}^{-1} \mathrm{~s}^{-1}$ within the current range of phenol concentrations (0.1-1\% i.e. $[\mathrm{AH}] \sim 10^{-3}-10^{-2} \mathrm{~mol} \mathrm{I}^{-1}$ ). 
The model simulation gives: $\left[\mathrm{P}^{\circ}\right] \sim 10^{-12} \mathrm{~mol}^{-1}$, $\left[\mathrm{POO}^{\circ}\right] \sim 10^{-8} \mathrm{~mol} \mathrm{l}^{-1}$ so that the inequality (2) is also fulfilled, but maybe less easily than inequality (1). It seems thus that inequality (1) brings the most satisfying explanation: (S3) reaction is less competitive in presence of oxygen. In other words, vitamin E loses its specificity in well oxygenated layers where (S1) and (S2) predominate over (S3) and (S4).

Comparison of Figures $5 \mathrm{a}$ and Figure $5 \mathrm{~b}$ shows that stabilization by $\mathrm{P}^{\circ}$ may become significant under radiolysis conditions in thick samples which can be explained as follows: irradiation generates $\mathrm{P}^{\circ}$ radicals within the whole thickness of sample. $\mathrm{P}^{\circ}$ radicals are scavenged by $\mathrm{O}_{2}$ to yield $\mathrm{POO}^{\circ}$ radicals in superficial layers where S1 and S2 reactions predominate hence over S3 and S4. In sample thick enough, a Diffusion Limited Oxidation phenomenon occurs (Gillen and Clough, 1992). $P^{\circ}$ radicals are present in the bulk and can either combine to yield crosslinking (which is used to obtain a wear resistant UHMWPE hips) or react with Vitamin E if this later was added prior to irradiation. It explains why adding vitamin E prior to irradiation induces a lower level of crosslink density for a given irradiation dose (Oral et al., 2005; Oral et al., 2008; Fu et al, 2013) since Vitamin E competes with irradiation induced crosslinking presumably by $\mathrm{P}^{\circ}+\mathrm{P}^{\circ}$ coupling contrarily to hindered phenols. Disposing of a model describing chemical changes in thick vitamin E stabilized PE sample under several dose rates may be a helpful tool for optimizing the design of hips for example.

Figure $5 \mathrm{~b}$ shows a maximum in vitamin $\mathrm{E}$ concentration at ca $0.5 \mathrm{~mm}$ depth, which is a criterion for validating the model. Some antioxidant profiles were reported in the case of UHMWPE displaying a vitamin $\mathrm{E}$ concentration gradient before irradiation. After irradiation, vitamin $\mathrm{E}$ residual concentration actually displays a maximum in the subsurface layers (Oral et al., 2007). This is an encouraging argument in favor of the model even if a most complete set of simulations is needed together with more accurate data on crystallinity profile, vitamin E and oxygen diffusivity etc... 


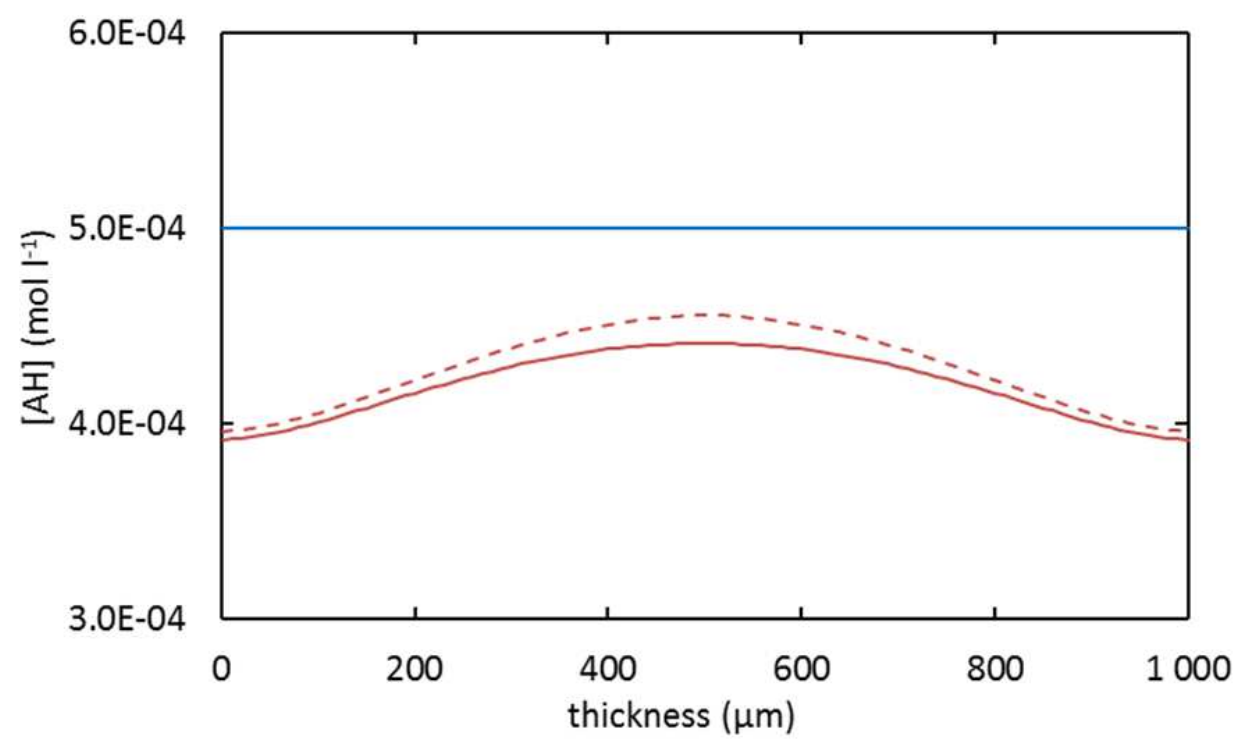

(a)

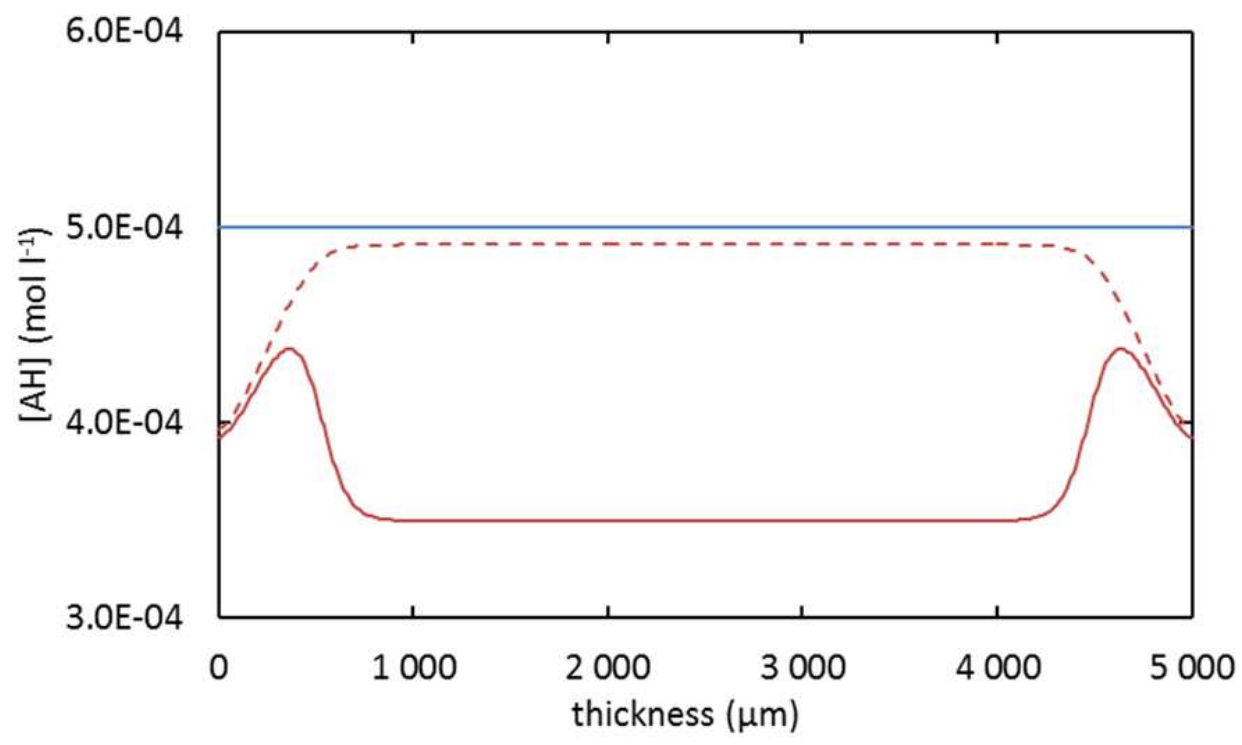

(b)

Figure 5. Simulation of Vitamin E depletion after $4 \mathrm{kGy}$ irradiation ( $1 \mathrm{kGy} \mathrm{h}^{-1}$ dose rate) with $\mathrm{k}_{\mathrm{S} 1}=500$ and $\mathrm{k}_{\mathrm{s} 2}=5.10^{8} \mathrm{I} \mathrm{mol}^{-1} \mathrm{~s}^{-1}$ in "thin" (a) and "thick" samples (b). $\mathrm{k}_{\mathrm{s} 3}=\mathrm{k}_{\mathrm{s} 4}=0$ (dashed line) or $\mathrm{k}_{\mathrm{s} 3}=7.5 \times 10^{4}$ and $\mathrm{k}_{\mathrm{s} 4}=10^{9} \mathrm{I} \mathrm{mol}^{-1} \mathrm{~s}^{-1}$ (full line) at $60^{\circ} \mathrm{C}$. 


\section{Effect of substituent on stabilization rate constants}

Mallégol et al. (2001c) reported depletion kinetics of vitamin E and other 2,6-di-tert-butylphenols under irradiation, which offers another possibility to determine the stabilization rate constants from inverse method. Given the possible sources of errors (such as the presence of residual phosphites leading to a strong synergy with phenols, irradiation induced temperature rise, crystallinity profile in the thickness modifying initial stabilizer repartition and diffusivity of oxygen and stabilizer), some discrepancy are expected with above reported values used for simulating Figures 1-3. However, those results offer at least a possibility to compare Vitamin E with a 2,6-di-tert-butyl phenols. The main difference with the study by Costa et al. (2009) recalled above is the thickness of the samples: $900 \mu \mathrm{m}$ instead of $180 \mu \mathrm{m}$. Hence, solution of the model gives the profile of residual phenols concentration during irradiation (see Figure 5). The concentration in the thickness is then averaged which gives the overall antioxidant concentration to be compared with results (Rincon Rubio et al., 2001). For this set of simulations:

- $D_{02}=8.10^{-7} \mathrm{~cm}^{2} \mathrm{~s}^{-1}$ comes from (Van Krevelen and Te Nijenhuis, 2009)

- $D_{A H}=5.2 \times 10^{-9} \mathrm{~cm}^{2} \mathrm{~s}^{-1}$ from Oral et al. (2006),

- $D_{A H}=9.2 \times 10^{-10} \mathrm{~cm}^{2} \mathrm{~s}^{-1}$ for AO1 from Roe et al. (1974), Moisan (1980), Limm and Hollifield (1996)

$-D_{A H}=2.3 \times 10^{-8} \mathrm{~cm}^{2} \mathrm{~s}^{-1}$ for AO2 from Moisan (1980). 


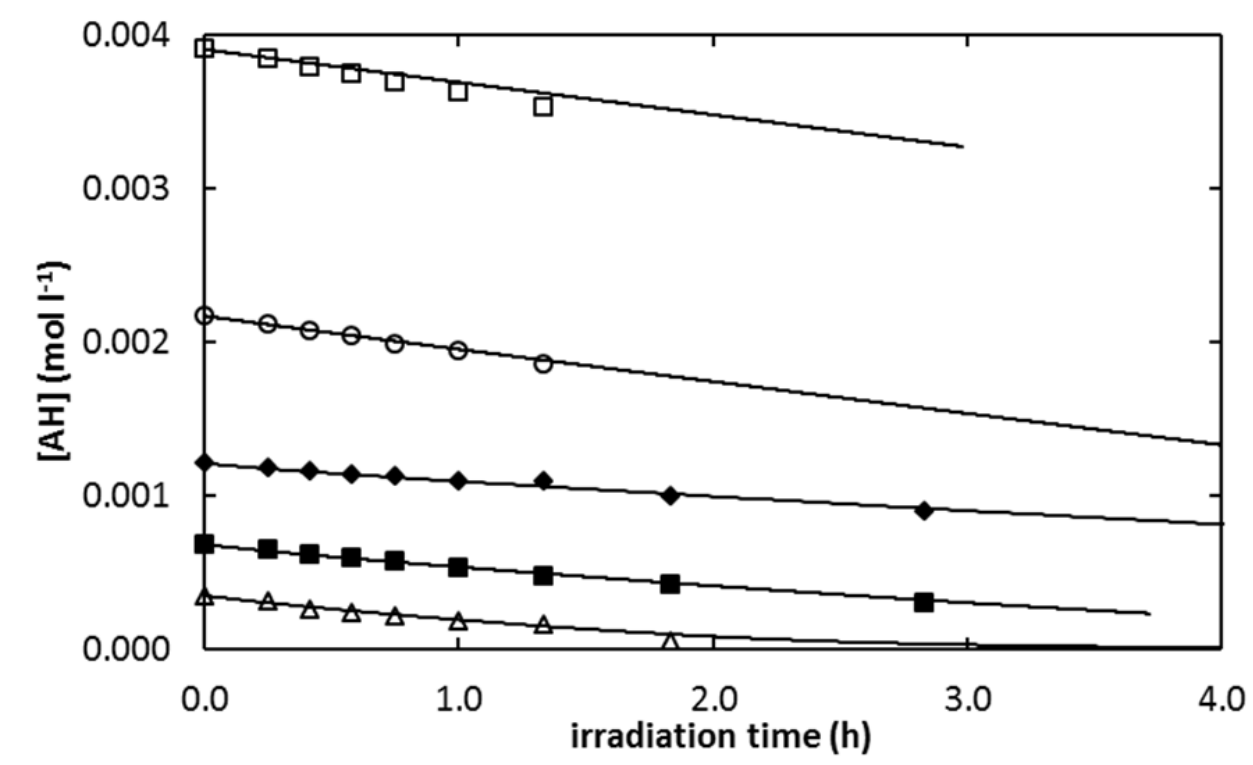

Figure 6. Depletion of antioxidant concentration during irradiation and modeling using rate constant of Table 1 ( : : 0.038\% AO1, $\mathbf{\square}: 0.016 \%$ AO2, $\square: 0.18 \%$ vitamin $E, O: 0.10 \%$ vitamin $E, \triangle: 0.016 \%$ vitamin E from Mallégol et al., 2001c) at $60^{\circ} \mathrm{C}$ at $60^{\circ} \mathrm{C}$.

Using rates constants recalled in Table 1, the model simulates the depletion of each sort of phenols using vitamin E rate constants differing with the 2,6-di-tert-butyl phenols set expressing by the presence of constants expressing the stabilization reaction by $\mathrm{P}^{\circ}$, and a higher rate constant $\mathrm{k}_{\mathrm{s} 1}$ for stabilization by $\mathrm{POO}^{\circ}$ trapping.

\begin{tabular}{|c|c|c|c|c|c|c|}
\hline stabilizer & $T$ & dose rate $\left(\mathrm{kGy} \mathrm{h}^{-1}\right)$ & $k_{s 1}$ & $k_{S 2}$ & $\mathrm{k}_{\mathrm{S3}}$ & $\mathrm{k}_{\mathrm{s} 4}$ \\
\hline Vitamin E & \multirow{3}{*}{ RT } & \multirow{3}{*}{1.25} & $2 \times 10^{4}$ & $5.10^{8}$ & $7.5 \times 10^{4}$ & $10^{9}$ \\
\hline $\mathrm{AO1}$ & & & $2.5 \times 10^{3}$ & $5.10^{8}$ & 0 & 0 \\
\hline $\mathrm{AO3}$ & & & $1 \times 10^{4}$ & $5.10^{8}$ & 0 & 0 \\
\hline Vitamin $\mathrm{E}$ & \multirow{2}{*}{$80^{\circ} \mathrm{C}$} & \multirow{2}{*}{0} & $2.5 \times 10^{3}$ & $5.10^{8}$ & $7.5 \times 10^{4}$ & $10^{9}$ \\
\hline $\mathrm{AO} 1$ & & & $1 \times 10^{3}$ & $5.10^{8}$ & 0 & 0 \\
\hline
\end{tabular}

Table 1. Rate constants used for simulating stabilization in HDPE during thermal or radio-thermal oxidation.

Then, we can turn to the modeling of kinetics of thermal ageing at $80^{\circ} \mathrm{C}$ for $\mathrm{PE}+$ vitamin $\mathrm{E}$ (Mallégol et al., 2001c) (Figure 7). Even if supposing that $E_{S 2}=E_{S 4}=0$, an infinity of $\left(k_{s 1}, k_{s 3}\right)$ pairs could permit to 
simulate those results. However, if $k_{s_{3}}$ influence is negligible in the investigated conditions (see Figures 4 and 5 ), then $k_{s 1}$ is here also the only adjustable parameter.

From the numerical solution of differential system, the model predicts the changes of carbonyls build up by the following equation:

$$
\frac{d[P=O]}{d t}=\left(1-x_{C}\right) \cdot\left(k_{1 u}[P O O H]+k_{1 b}[P O O H]^{2}+k_{62}\left[P O^{\circ} O P\right]_{\text {cage }}+2 k_{63}\left[P O^{\circ} O P\right]_{\text {cage }}\right)
$$

that can be compared with experimental results (Figure 7):

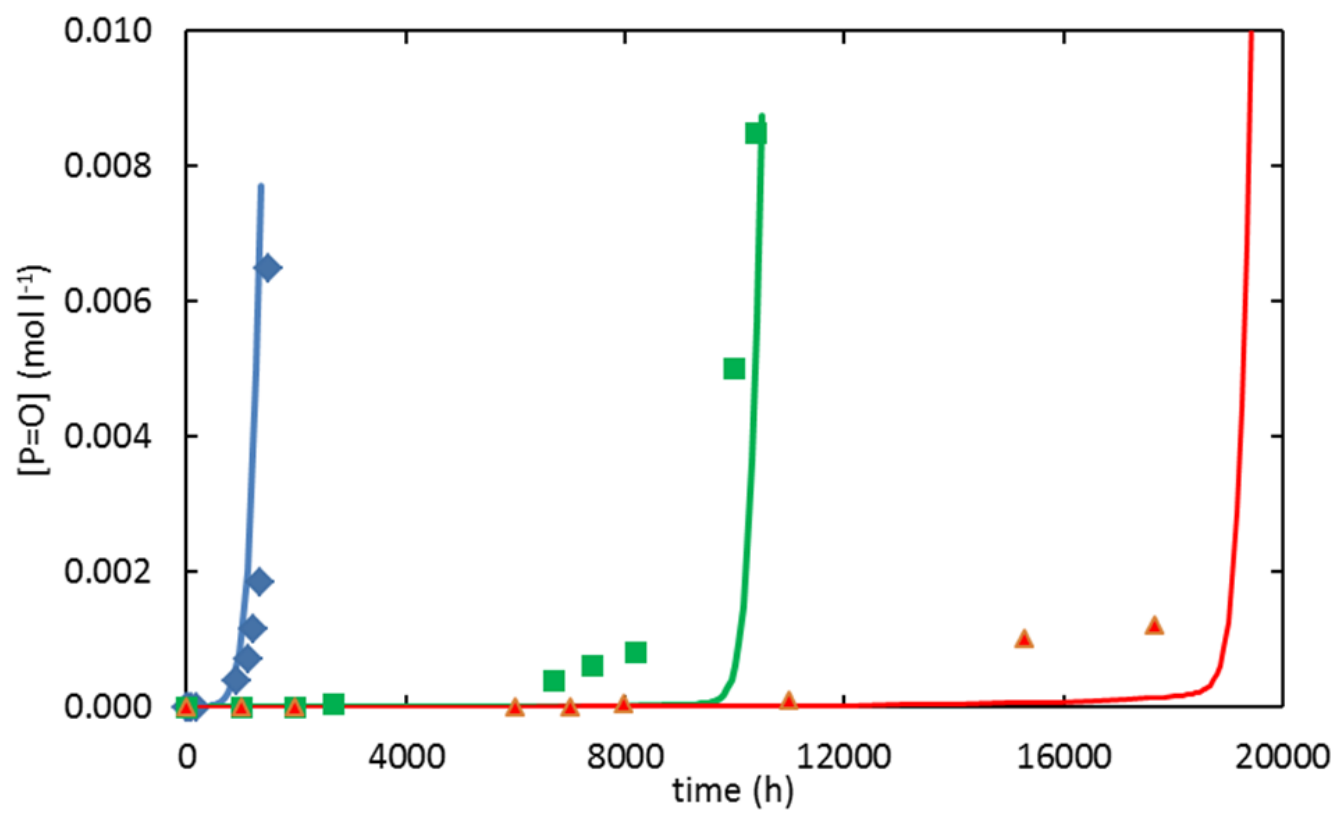

Figure 7. Experimental kinetics of carbonyl build-up during thermal oxidation at $80^{\circ} \mathrm{C}$ from Mallégol et al., 2001c for pure HDPE ( ) , HDPE + 0.016\% Vitamin E ( $\mathbf{\square}), \mathrm{HDPE}+0.038 \% \mathrm{AO}(\mathbf{\Delta})$ and simulations by the model with $\mathrm{k}_{\mathrm{S} 1} \ldots \mathrm{k}_{\mathrm{s} 4}$ values given in Table 1.

As for simulations of Figure $6, \mathrm{k}_{\mathrm{s} 1}($ vitamin $\mathrm{E})$ is about twice the one for AO1 which is ascribed to a lower hindrance (or protection) of the phenol $-\mathrm{OH}$ group. Those $\mathrm{k}_{\mathrm{S} 1}$ values of vitamin $\mathrm{E}$ were plotted in an Arrhenius diagram (Figure 8) together with values determined from AO1 for which a lot of 
values were compiled in the case of thermal oxidation (Richaud, 2013) and those determined from Figure 2:

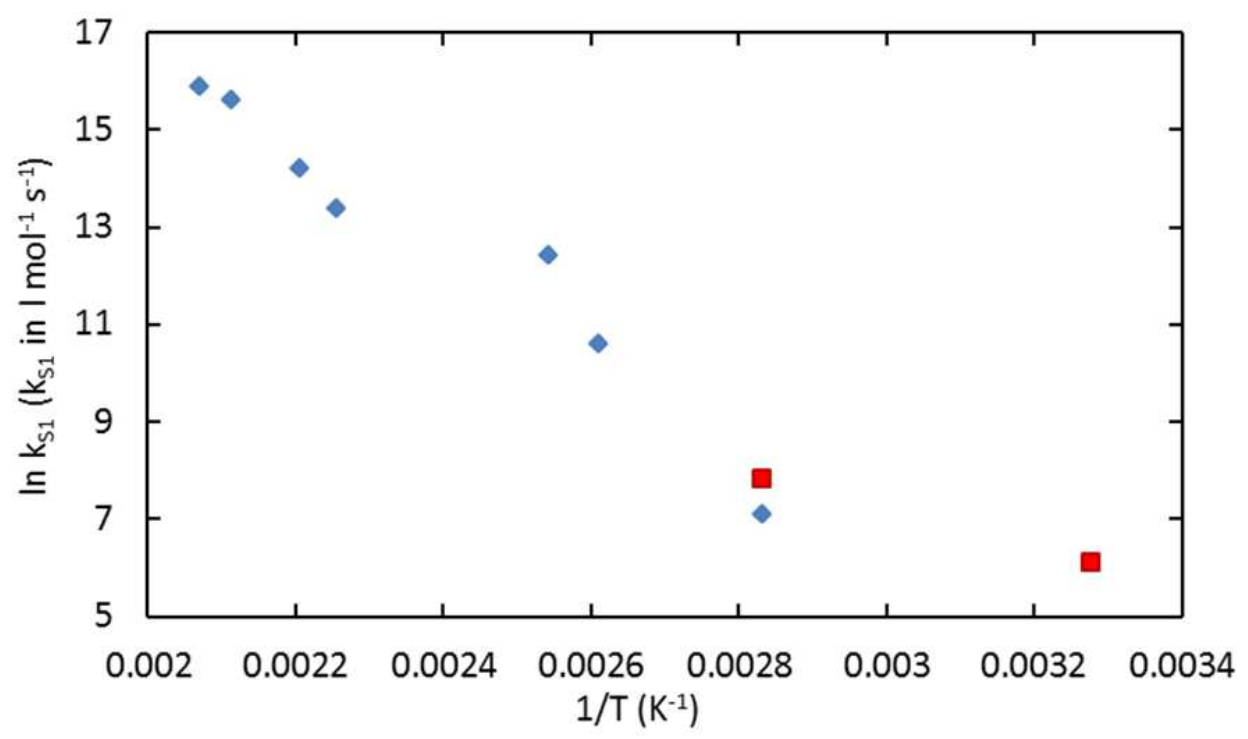

Figure 8. Arrhenius diagram for stabilization rate constant $k_{\mathrm{S1}}$ for vitamin $\mathrm{E}(\boldsymbol{\square}$, determined in this work) and AO1 ( from Richaud, 2013).

We will not speculate here on the possible activation energy of $k_{s_{1}}$ (vitamin $E$ ) the low temperature data is expected to correspond to irradiation at room temperature whereas it is known that irradiation induces a slight heating of sample (Costa et al., 2008). However, it seems clear that:

- Vitamin E differ from 2,6-di-tert-butyl phenols by its ability to react with both $\mathrm{P}^{\circ}$ and $\mathrm{POO}^{\circ}$.

- $\mathrm{POO}^{\circ}$ react faster with vitamin $\mathrm{E}$ than with 6-di-tert-butyl phenols because of lower hindrance. However, placing its rate constants for $\mathrm{POO}^{\circ}+\mathrm{AH} \rightarrow \mathrm{POOH}+\mathrm{A}^{\circ}$ reaction in the same Arrhenius diagram shows that the order of magnitude is the same, because of $\mathrm{O}-\mathrm{H}$ bond dissociation energy remains almost unchanged compared to $\mathrm{AO}$.

Let us now turn to phenolic antioxidants with a "hybrid" structure (i.e. with only one tert-butyl ortho substituent) for example AO4. For that purpose, we compiled some Oxidation Induction Time monitored by DSC or Chemiluminescence of $\mathrm{PE}+\mathrm{AO} 1, \mathrm{AO} 3$ and $\mathrm{AO} 4$ :

- The stabilizer weight fraction was converted into nominal phenol concentration. 
- We compared data series only differing by the nature of the stabilizer (for a given polymer grade) to avoid the possible scattering induced by the intrinsic level of impurities (catalyst, double bonds, short branching...) depending on the polyethylene grade (HDPE vs LDPE).

- We focused only on molten state data for avoiding uncertainties linked to the crystallinity effect.

- Last, since it is known that molten state degradation may be heterogeneous because of Diffusion Limited Oxidation, we focused on the early stage of degradation characterized by OIT (corresponding to the time at which diffusion gradient appear (Rincon-Rubio et al., 2001).

Results are presented in Figure 9. Despite their differences in molar mass $\left(531 \mathrm{~g} \mathrm{~mol}^{-1}\right.$ for AO3, 696 for $\mathrm{AO} 4$ and 1176 for $\mathrm{AO} 1)$, the slopes OIT vs $[\mathrm{AH}]$ are rather close indicating that those stabilizers display certainly the same set of rate constants, contrarily to the comparison of vitamin E with AO1 and $\mathrm{AO} 2$ in Breese et al. (2000).

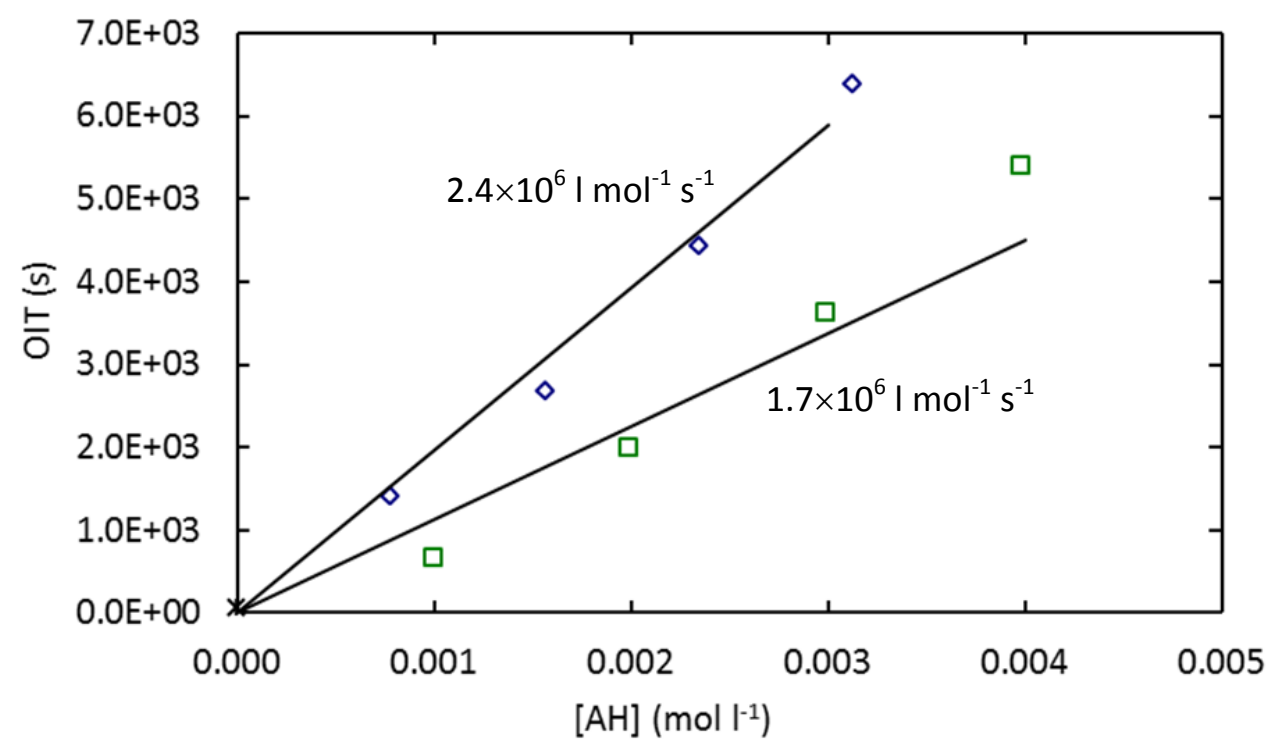

(a) 


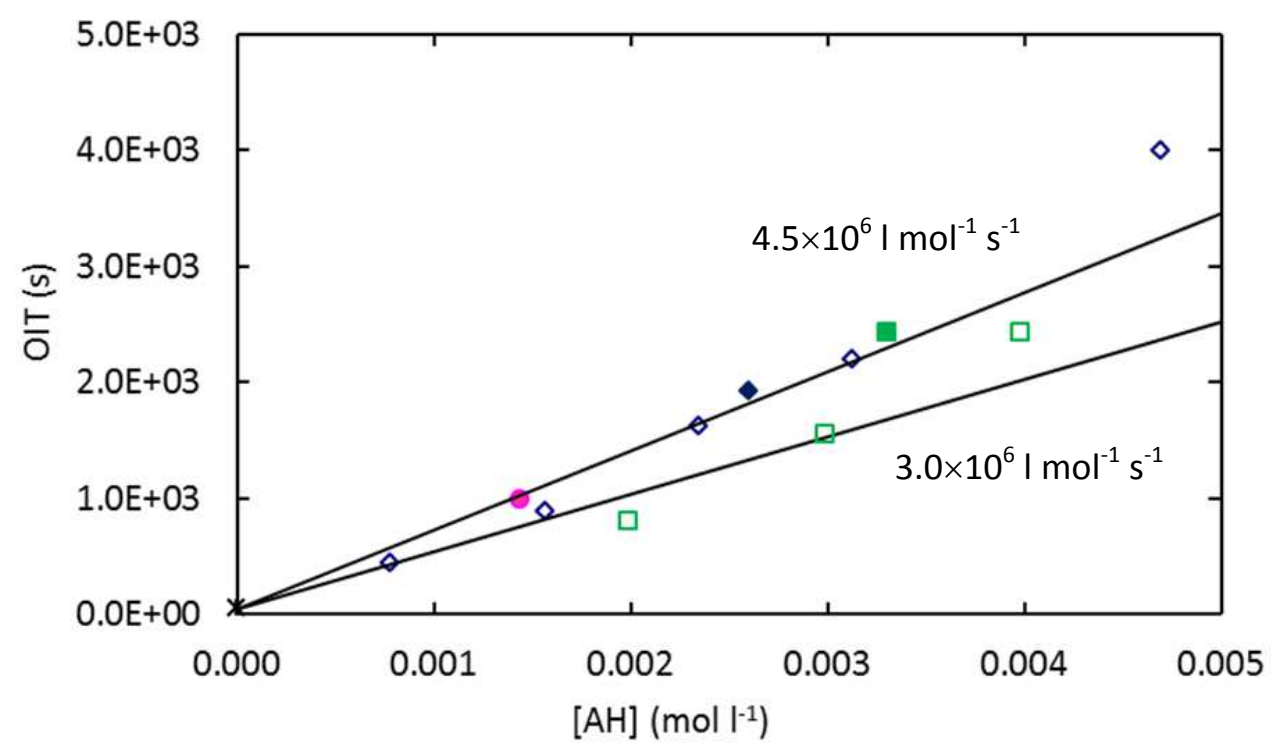

(b)

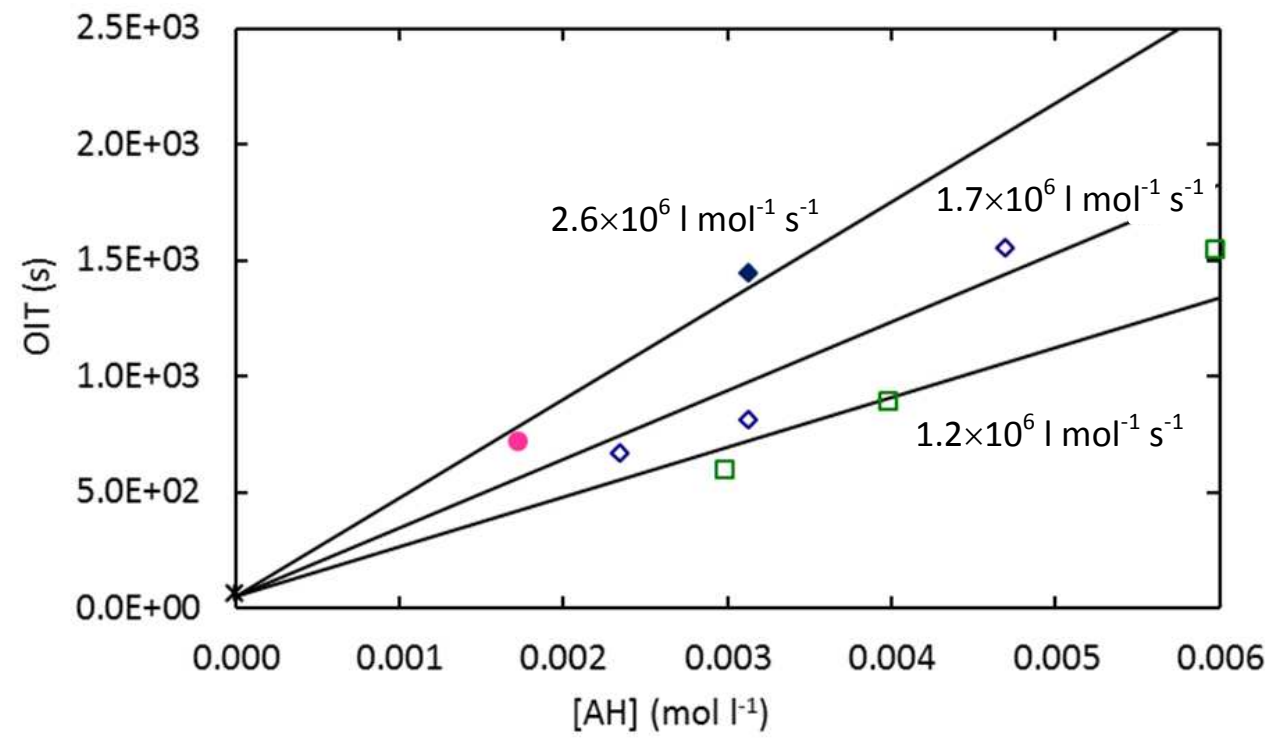

(c)

Figure 9. Oxidation Induction Time versus nominal phenol concentration at $190^{\circ} \mathrm{C}$ ( $*$ : pure $\mathrm{PE}, \diamond: \mathrm{PE}$ + AO1, $\square: P E+A O 4$ from Latocha and Uhniat (1992), 200 ${ }^{\circ} \mathrm{C}$ (* : pure PE, $\diamond: P E+A O 1, \square: P E+A O 4$ from Latocha and Uhniat (1992), @: PE + AO3, $\mathbf{0}: P E+A O 4, \bullet: P E+A O 1$ from Peña et al. (2000), $210^{\circ} \mathrm{C}$ (*: pure PE, $\diamond: P E+A O 1, \square: P E+A O 4$ from Latocha and Uhniat (1992), @: PE + AO3, $\bullet: P E+$ AO1 from $\varnothing$ gaard Madsen et al. (1985). Straight lines correspond to simulation by the model with several $\mathrm{k}_{\mathrm{S} 1}$ values, $\mathrm{k}_{\mathrm{S} 2}=5 \times 10^{8} \mathrm{I} \mathrm{mol}^{-1} \mathrm{~s}^{-1}, \mathrm{k}_{\mathrm{S} 3}=\mathrm{k}_{\mathrm{S} 4}=0$ and $[\mathrm{POOH}]_{0}=10^{-4} \mathrm{~mol} \mathrm{I}^{-1}$. 
As discussed in Richaud and al. (2011), those OIT versus phenol plot can be simulated by the model using a set of $\mathrm{k}_{\mathrm{S} 1}$ value (for expressing the stabilizer efficiency) and $[\mathrm{POOH}]_{0}$ expressing the level of unstable impurities in polymer i.e. an intrinsic characteristic of each polymer grade.

Here, in the absence of valuable information on $[\mathrm{POOH}]_{0}$ for each sort of $\mathrm{PE}$ grade, our aim is not to determine the "true" $k_{\mathrm{S} 1}$ value for each sort of stabilizer but rather to compare the efficiency of each sort of antioxidants expressed by $k_{\mathrm{S} 1}$ for each $\mathrm{AO}$. This comparison is henceforward valid only for a given PE grade (i.e. only for open or closed symbols in Figure 9).

It is found that $\mathrm{AO}, \mathrm{AO} 2$ and $\mathrm{AO} 4$ display rate constant equal (close symbols in Figure 9b and 9c) or no more than 1.5 times different (open symbols in Figure 9a). Let us precise that the evaporation of the molecules with lowest molar mass e.g. AO4 vs AO1 leads to an underestimation of $\mathrm{k}_{\mathrm{S} 1}$ (Richaud et al., 2009). This would even explain a part of the difference between $k_{s 1}(A O 1), k_{s 1}(A O 2)$ and $k_{S 1}(A O 4)$, when this difference exists.

In other words, there would is only very slight difference between stabilizers having one or two ditert-butyl ortho substituents compared to $\mathrm{AO} 1$ and $\mathrm{AO} 2$ vs vitamin $\mathrm{E}$ (Table 1). AO1...AO4 only react by trapping $\mathrm{POO}^{\circ}$. The explanation is out of the scope of the present paper and remains open.

3. Effect of radiochemical initiation on phenol efficiency

In their original work, Clough and Gillen (1990) already illustrated the efficiency of a phenol stabilizer at $200 \mathrm{kGy} \mathrm{h}^{-1}$ dose rate. Here, the kinetic model permits in principle to estimate this efficiency in a wider range of exposure conditions.

The sets of rate constants (Table 1) used for simulating Figure 7 were kept for running simulations differing by the dose rate value. This set of simulations is aimed at understanding the changes of stabilizer efficiency for inhibiting degradation phenomena changing with incident dose rate (Gillen and Clough, 1981), according to kinetic model and the effect of hindrance on radio thermal stabilization. 
Examples of kinetic curves for $\mathrm{POOH}$ are given in Figure 10 at dose rate equal to 1 and $100 \mathrm{~Gy} \mathrm{~s} \mathrm{~s}^{-1}$ at $80^{\circ} \mathrm{C}$. The induction period vanishes progressively when increasing dose rate. At dose rates above $1000 \mathrm{~Gy} \mathrm{~s}^{-1}$, curves for pure and stabilized PE are almost undistinguishable meaning that phenolic antioxidants turn to be ineffective.

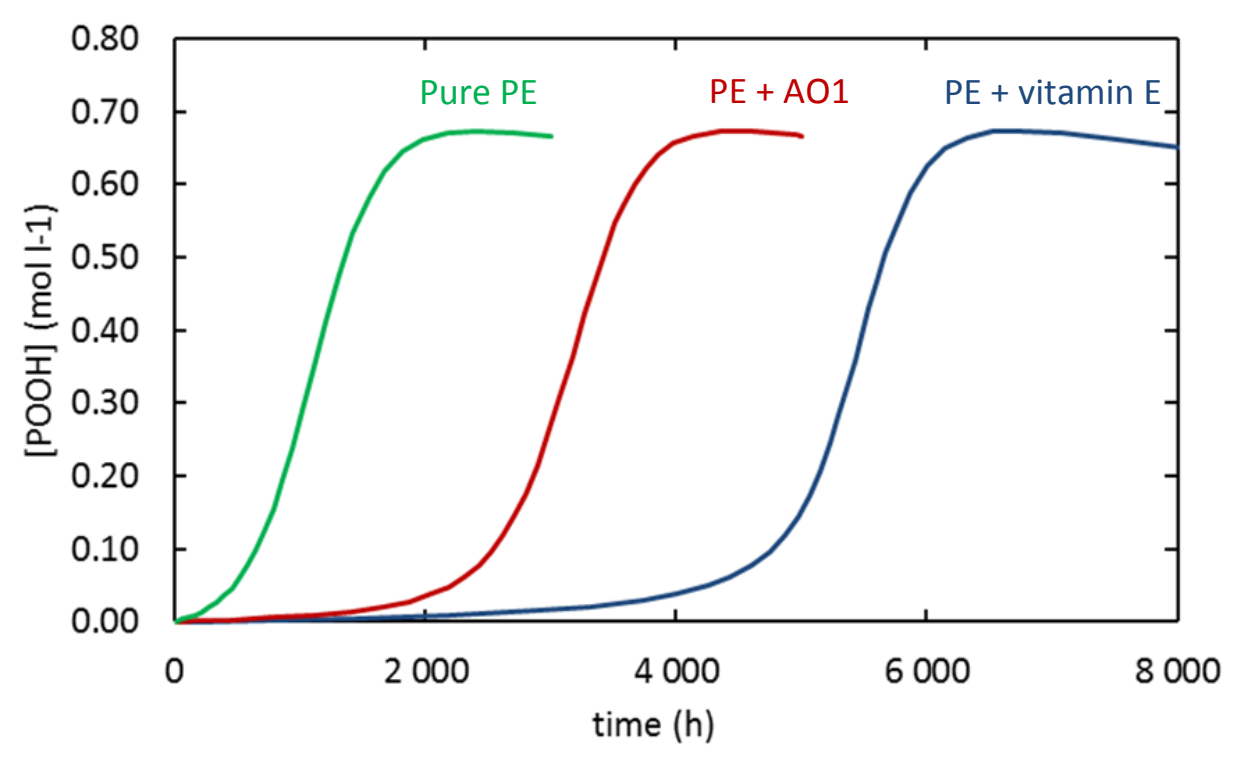

(a)

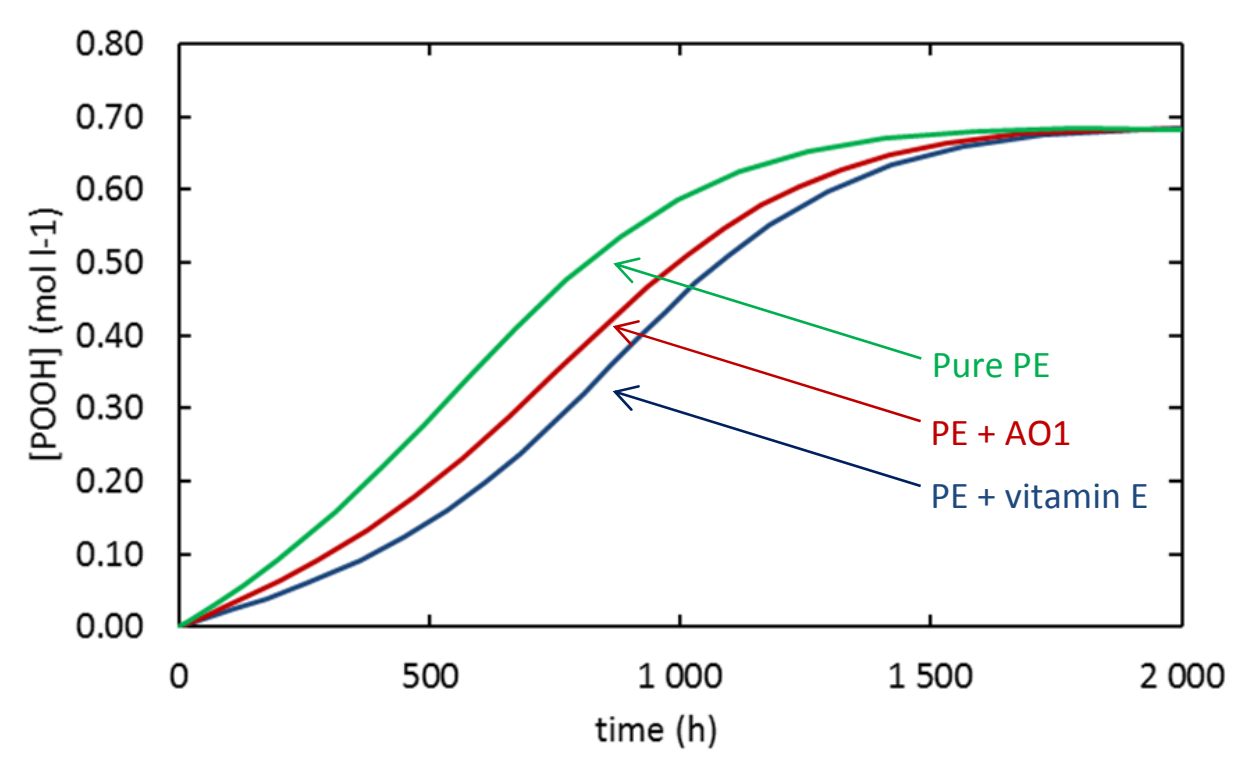

(b)

Figure 10. Simulations of kinetic curves for $\mathrm{POOH}$ appearance at $80^{\circ} \mathrm{C}$ under 1 and $100 \mathrm{~Gy} \mathrm{~s}^{-1}$ for pure $\mathrm{PE}, \mathrm{PE}+0.001 \mathrm{~mol} \mathrm{I}^{-1}$ vitamin $\mathrm{E}$ or $\mathrm{PE}+0.001 \mathrm{~mol} \mathrm{I}^{-1}$ of 2,6-di-tert-butyl phenols. 
Curves always display a maximal level $\left([\mathrm{POOH}]_{\max }\right)$ independent of the dose rate value. According to Khelidj et al. (2005), polyethylene reaches a critical level of properties when $[\mathrm{POOH}] \sim[\mathrm{POOH}]_{\max } / \mathrm{q}, \mathrm{q}$ being equal to 13 at room temperature. We kept here the same value, in the sake of simplicity. Corresponding lifetime values for pure PE, PE $+0.001 \mathrm{~mol} \mathrm{I}^{-1} \mathrm{AO}$ (or any other 2,6-di-tert-butyl phenol) and PE $+0.001 \mathrm{~mol} \mathrm{I}^{-1}$ vitamin $\mathrm{E}$ are placed in Figure 11:

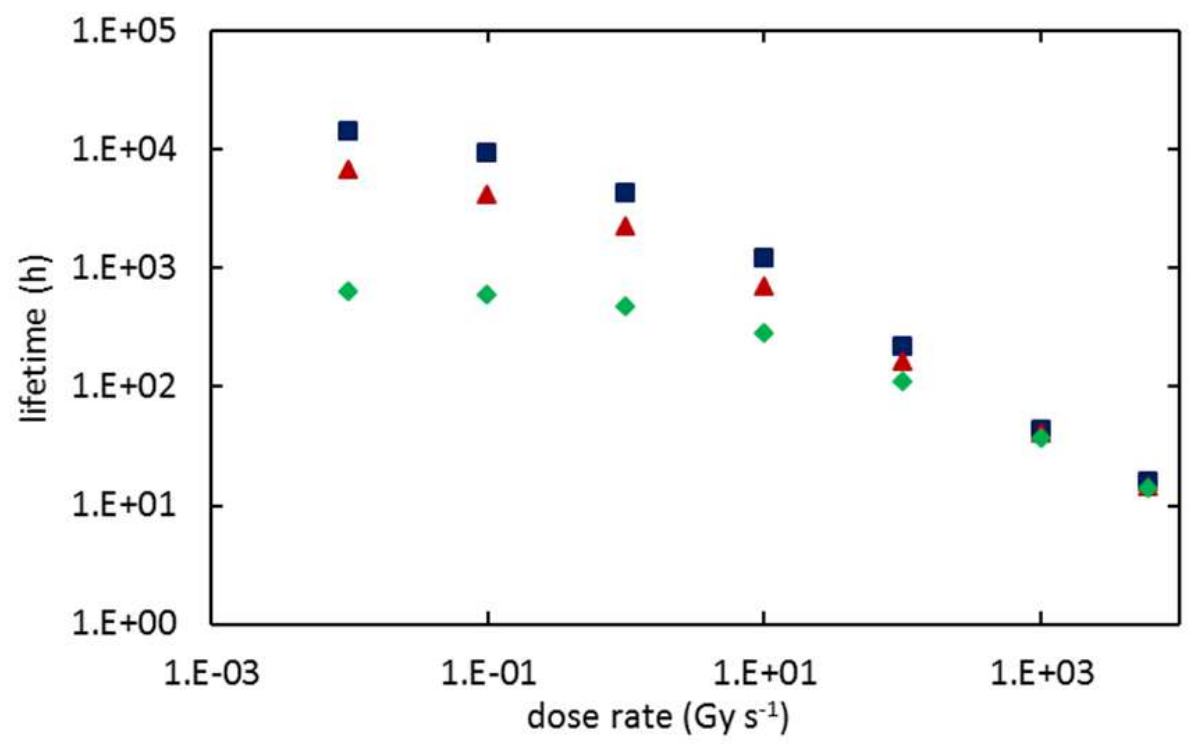

Figure 11. Lifetime versus dose rate for pure PE $(\bullet), P E+0.001 \mathrm{~mol} \mathrm{I}^{-1} 2,6$-di-tert-butyl phenol $(\boldsymbol{\Delta})$ or vitamin $\mathrm{E}(\mathbf{\square})$ simulated by model with rate constants given in Table 1.

Figure 10 and 11 show that both sorts of phenols are inefficient for inhibiting radio-thermal oxidation at high dose rate. This is not surprising since, as recalled in the "INTRODUCTION" of this manuscript, phenols are particularly well adapted for thermal oxidation of polyolefins where the kinetic chain length is great, contrarily to "pure" radiochemical oxidation characterized by a fast initiation kinetic and a lower $\mathrm{KCL}$. However, vitamin $\mathrm{E}$ can efficiently trap $\mathrm{P}^{\circ}$ radicals during a high dose rate exposure thus preventing undesired crosslinking of the polymer.

On the contrary, when lowering dose rate, both sort of phenol stabilize PE against oxidation. Due to a lower hindrance, vitamin E reacts faster with $\mathrm{POO}^{\circ}$ radicals and seems to be more efficient. 


\section{CONCLUSIONS}

Most of the literature on polyolefin oxidation considers that phenols trap $\mathrm{POO}^{\circ}$ radicals. From a kinetic point of view, a stabilization effect is observed if :

$$
\mathrm{k}_{\mathrm{s} 1}\left[\mathrm{POO}^{\circ}\right][\mathrm{AH}]>>\mathrm{k}_{3}\left[\mathrm{POO}^{\circ}\right][\mathrm{PH}]
$$

Hence, phenols are actually expected to be efficient stabilizers since:

$$
\begin{aligned}
& \mathrm{BDE}(\mathrm{C}-\mathrm{H}) \sim 390 \mathrm{~kJ} \mathrm{~mol}^{-1} \\
& \mathrm{BDE}(\mathrm{O}-\mathrm{H}) \sim 340 \mathrm{~kJ} \mathrm{~mol}^{-1}
\end{aligned}
$$

Since $\operatorname{BDE}(\mathrm{O}-\mathrm{H})$ is almost the same in vitamin $\mathrm{E}$ and in 2,6-di-tert-butyl-phenols, both sort of antioxidant should have a very comparable efficiency in PE. However, a review of literature shows that vitamin $\mathrm{E}$ is a particular sort of phenol because it reacts with $\mathrm{P}^{\circ}$, and its reaction with $\mathrm{POO}^{\circ}$ has a higher rate constant than 2,6-di-tert-butyl phenol. This is ascribed here to a lower hindrance of phenol making the $\mathrm{O}-\mathrm{H}$ group more accessible in vitamin $\mathrm{E}$ than in tert-butyl phenols substituted in 2 and 6 or simply 2 position. The compiled data were used for estimating sets of rate constants for each sort of stabilizers and complete the existing model for PE + antioxidant. This one was here validated from its ability to simulate stabilizer depletion curve during PE radiochemical ageing, and used in several conditions for estimating the changes of phenol efficiency with dose rate.

\section{ACKNOWLEDGEMENTS}

Science et Médecine company (Créteil - France) is gratefully acknowledged for having funded this research work. Dr Frédéric Bréard is acknowledged for fruitful talks. 
APPENDIX A: Structure of stabilizers

AO1 (CAS NO. 6683-19-8)
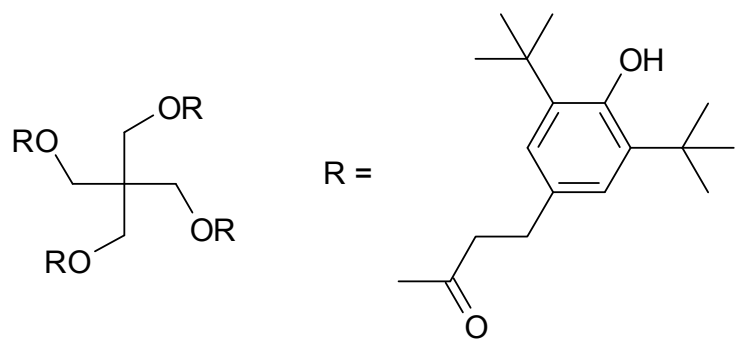

$\mathrm{AO} 2$<smiles>Cc1cc(C(C)(C)C)c(O)c(C(C)(C)C)c1</smiles>

AO3 (CAS NO. 2082-79-3)<smiles>CCCCCCCCCCCCCCCCCOC(=O)CCc1cc(C(C)(C)C)c(O)c(C(C)(C)C)c1</smiles>

AO4 (CAS NO. 40601-76-1)<smiles>Cc1cc(Cn2c(=O)n(Cc3cc(C)c(O)c(C)c3C)c(=O)n(Cc3cc(C)c(O)c(C(C)(C)C)c3C)c2=O)c(C)c(C)c1O</smiles> 
APPENDIX B: Kinetic modeling

The mechanistic scheme for polyethylene radio thermal oxidation was established by Khelidj et al (2006):

$\begin{array}{ll}\mathrm{PH}+\mathrm{h} v \rightarrow \mathrm{P}^{\circ}+1 / 2 \mathrm{H}_{2} & \mathrm{r}_{\mathrm{i}}=10^{-7} \times \mathrm{G}\left(\mathrm{P}^{\circ}\right) \times \mathrm{I} \\ \mathrm{POOH} \rightarrow 2 \mathrm{P}^{\circ}+\gamma_{1} \mathrm{P}=\mathrm{O}+\gamma_{2} \mathrm{~S} & \mathrm{k}_{1 \mathrm{u}} \\ \mathrm{POOH}+\mathrm{POOH} \rightarrow \mathrm{P}^{\circ}+\mathrm{POO}^{\circ}+\gamma_{1} \mathrm{P}=\mathrm{O}+\gamma_{2} \mathrm{~S} & \mathrm{k}_{1 b} \\ \mathrm{P}^{\circ}+\mathrm{O}_{2} \rightarrow \mathrm{POO} & \mathrm{k}_{2} \\ \mathrm{POO}+\mathrm{PH} \rightarrow \mathrm{POOH}+\mathrm{P}^{\circ} & \mathrm{k}_{3} \\ \mathrm{P}^{\circ}+\mathrm{P}^{\circ} \rightarrow \gamma_{4} \mathrm{Cross} \text { link }+\left(1-\gamma_{4}\right)>\mathrm{C}=\mathrm{C}< & \mathrm{k}_{4} \\ \mathrm{P}^{\circ}+\mathrm{POO}{ }^{\circ} \rightarrow\left(1-\gamma_{5}\right) \mathrm{POOP}+\gamma_{5} \mathrm{POOH}+\gamma_{5}>\mathrm{C}=\mathrm{C}< & \mathrm{k}_{5} \\ \mathrm{POO}^{\circ}+\mathrm{POO} \rightarrow\left[\mathrm{PO}{ }^{\circ} \mathrm{OP}\right]_{\text {cage }}+\mathrm{O}_{2} & \mathrm{k}_{60} \\ {\left[\mathrm{PO}^{\circ}{ }^{\circ} \mathrm{OP}\right]_{\text {cage }} \rightarrow \mathrm{POOP}+\mathrm{x}} & \mathrm{k}_{61} \\ {\left[\mathrm{PO}^{\circ}{ }^{\circ} \mathrm{OP}\right]_{\text {cage }} \rightarrow \mathrm{POH}+\mathrm{P}=\mathrm{O}} & \mathrm{k}_{62} \\ {\left[\mathrm{PO}^{\circ}{ }^{\circ} \mathrm{OP}\right]_{\text {cage }} \rightarrow 2 \mathrm{P}^{\circ}+\gamma_{1} \mathrm{P}=\mathrm{O}+\mathrm{s}} & \mathrm{k}_{63}\end{array}$

where:

- $\mathrm{P}^{\circ}, \mathrm{POO}^{\circ},\left[\mathrm{PO}{ }^{\circ} \mathrm{OP}\right]_{\text {cage, }} \mathrm{POOH}$ are respectively alkyl, peroxy, in cage alkoxy radicals, and hydroperoxides.

- $\mathrm{P}=\mathrm{O}, \mathrm{s}, \mathrm{x}$ and $>\mathrm{C}=\mathrm{C}<$ are respectively carbonyl compounds, chain scissions, crosslink nodes, and double bonds.

$-k_{1 u}, k_{1 b} \ldots k_{63}$ are the rate constants of the kinetic scheme. Values previously determined for common additive free polyethylene grades (HDPE, LDPE) will be used here even for UHMWPE, since reactive unit is in each case the methylene group $-\mathrm{CH}_{2}-$.

- $\gamma_{1}, \gamma_{2}, \gamma_{4}$ and $\gamma_{5}$ are respectively yields for carbonyl and chain scissions from POOH decomposition, double bond from $\mathrm{P}^{\circ}$ disproportionation and hydroperoxide from $\mathrm{P}^{\circ}+\mathrm{POO}^{\circ}$ dismutation.

$-G\left(P^{\circ}\right)$ is the radiochemical yield of radical creation.

Values of those parameters are given in Table 1 and 2: 


\begin{tabular}{|c|c|c|}
\hline $\begin{array}{c}\text { Rate } \\
\text { constant }\end{array}$ & Pre-exponential factor & Activation energies \\
\hline$k_{1 \mathrm{u}}$ & $8.0 \times 10^{12} \mathrm{~s}^{-1}$ & $140 \mathrm{~kJ} \mathrm{~mol}^{-1}$ \\
$\mathrm{k}_{1 \mathrm{~b}}$ & $2.8 \times 10^{9} \mathrm{I} \mathrm{mol}^{-1} \mathrm{~s}^{-1}$ & $105 \mathrm{~kJ} \mathrm{~mol}^{-1}$ \\
$\mathrm{k}_{2}$ & $1.0 \times 10^{8} \mathrm{I} \mathrm{mol}^{-1} \mathrm{~s}^{-1}$ & $0 \mathrm{~kJ} \mathrm{~mol}^{-1}$ \\
$\mathrm{k}_{3}$ & $1.5 \times 10^{10} \mathrm{I} \mathrm{mol}^{-1} \mathrm{~s}^{-1}$ & $73 \mathrm{~kJ} \mathrm{~mol}^{-1}$ \\
$\mathrm{k}_{4}$ & $8.0 \times 10^{11} \mathrm{I} \mathrm{mol}^{-1} \mathrm{~s}^{-1}$ & $0 \mathrm{~kJ} \mathrm{~mol}^{-1}$ \\
$\mathrm{k}_{5}$ & $2.3 \times 10^{11} \mathrm{I} \mathrm{mol}^{-1} \mathrm{~s}^{-1}$ & $0 \mathrm{~kJ} \mathrm{~mol}^{-1}$ \\
$\mathrm{k}_{60}$ & $4.9 \times 10^{19} \mathrm{I} \mathrm{mol}^{-1} \mathrm{~s}^{-1}$ & $80 \mathrm{~kJ} \mathrm{~mol}^{-1}$ \\
$\mathrm{k}_{61}$ & $2.0 \times 10^{6} \mathrm{~s}^{-1}$ & $0 \mathrm{~kJ} \mathrm{~mol}^{-1}$ \\
$\mathrm{k}_{62}$ & $1.2 \times 10^{5} \mathrm{~s}^{-1}$ & $5 \mathrm{~kJ} \mathrm{~mol}^{-1}$ \\
$\mathrm{k}_{63}$ & $8.0 \times 10^{12} \mathrm{~s}^{-1}$ & $50 \mathrm{~kJ} \mathrm{~mol}^{-1}$ \\
\hline
\end{tabular}

Table 1. Values of pre-exponential factor and activation energy of rates constants (Khelidj et al., 2006).

\begin{tabular}{|c|c|c|}
\hline$G\left(P^{\circ}\right)$ & 8 & \\
$\gamma_{1}$ & 0.2 & \\
$\gamma_{2}$ & 1 at $60^{\circ} \mathrm{C}$ & 0.95 at $80^{\circ} \mathrm{C}$ \\
$\gamma_{4}$ & 0.5 & \\
$\gamma_{5}$ & 0.5 & \\
\hline
\end{tabular}

Table 2. Values of yields (see text, from Khelidj et al., 2006).

According to this work, and other previous papers (Richaud et al., 2008, Richaud et al., 2011, Richaud, 2013), the action of stabilizers is can be described by adding the following equations to the general mechanistic scheme:
$\mathrm{AH}+\mathrm{POO}^{\circ} \rightarrow \mathrm{POOH}+\mathrm{A}^{\circ}$
$\mathrm{k}_{\mathrm{s} 1}$
$\mathrm{A}^{\circ}+\mathrm{POO}^{\circ} \rightarrow$ inactive product
$\mathrm{k}_{\mathrm{s} 2}$
$\mathrm{AH}+\mathrm{P}^{\circ} \rightarrow \mathrm{A}^{\circ}$
$k_{s 3}$
$\mathrm{A}^{\circ}+\mathrm{P}^{\circ} \rightarrow$ inactive product
$\mathrm{k}_{\mathrm{s} 4}$ 
$\mathrm{AH}$ represents a phenolic antioxidant (for example if $\mathrm{AH}$ is a di-tert-butyl phenol, $\mathrm{k}_{\mathrm{s} 3}=\mathrm{k}_{\mathrm{s} 4}=0$, see Richaud et al., 2008, Richaud et al., 2011, Richaud, 2013). The following set of differential equations is derived:

$$
\begin{aligned}
& \frac{d\left[\mathrm{P}^{\circ}\right]}{d t}=2 \mathrm{k}_{1 \mathrm{u}}[\mathrm{POOH}]+\mathrm{k}_{1 \mathrm{~b}}[\mathrm{POOH}]^{2}-\mathrm{k}_{2}\left[\mathrm{P}^{\circ}\right]\left[\mathrm{O}_{2}\right]+\mathrm{k}_{3}\left[\mathrm{POO}^{\circ}\right][\mathrm{PH}]+2 \mathrm{k}_{63}\left[\mathrm{PO}{ }^{\circ} \mathrm{OP}\right]_{\text {cage }} \\
& -k_{S 3}\left[P^{\circ}\right][A H]+k_{S 4}\left[P^{\circ}\right]\left[A^{\circ}\right] \\
& \frac{d\left[\mathrm{POO}^{\circ}\right]}{d t}=k_{1 b}[\mathrm{POOH}]^{2}+k_{2}\left[\mathrm{P}^{\circ}\right]\left[\mathrm{O}_{2}\right]-\mathrm{k}_{3}\left[\mathrm{POO}^{\circ}\right][\mathrm{PH}]-2 \mathrm{k}_{60}\left[\mathrm{POO}^{\circ}\right]^{2} \\
& -\mathrm{k}_{\mathrm{S} 1}\left[\mathrm{POO}^{\circ}\right][\mathrm{AH}]-\mathrm{k}_{\mathrm{S} 2}\left[\mathrm{POO}^{\circ}\right]\left[\mathrm{A}^{\circ}\right] \\
& \frac{d[\mathrm{POOH}]}{d t}=-\mathrm{k}_{1 \mathrm{u}}[\mathrm{POOH}]-2 \mathrm{k}_{1 \mathrm{~b}}[\mathrm{POOH}]^{2}+\mathrm{k}_{3}\left[\mathrm{POO}^{\circ}\right][\mathrm{PH}]+\mathrm{k}_{\mathrm{S} 1}\left[\mathrm{POO}^{\circ}\right][\mathrm{AH}] \\
& \frac{d\left[\mathrm{PO}^{\circ} \mathrm{OP}\right]_{\mathrm{Cage}}}{d t}=k_{60}\left[\mathrm{POO}^{\circ}\right]^{2}-\left(\mathrm{k}_{61}+\mathrm{k}_{62}+\mathrm{k}_{63}\right)\left[\mathrm{PO}^{\circ} \mathrm{OP}\right]_{\text {cage }} \\
& \frac{\partial\left[\mathrm{O}_{2}\right]}{\partial \mathrm{t}}=\mathrm{k}_{60}\left[\mathrm{POO}^{\circ}\right]^{2}-\mathrm{k}_{2}\left[\mathrm{P}^{\circ}\right]\left[\mathrm{O}_{2}\right]+\mathrm{D}_{\mathrm{O} 2} \cdot \frac{\partial^{2}\left[\mathrm{O}_{2}\right]}{\partial \mathrm{x}^{2}} \\
& \frac{d[A H]}{d t}=-k_{S 1}\left[P O O^{\circ}\right][A H]-k_{S 3}\left[P^{\circ}\right][A H]+D_{A H} \cdot \frac{\partial^{2}[A H]}{\partial x^{2}} \\
& \frac{d\left[A^{\circ}\right]}{d t}=k_{S 1}\left[P O O^{\circ}\right][A H]+k_{S 3}\left[P^{\circ}\right][A H]-k_{S 2}\left[P O O^{\circ}\right]\left[A^{\circ}\right]-k_{S 4}\left[P^{\circ}\right]\left[A^{\circ}\right]
\end{aligned}
$$

The sample having a thickness equal to $L$ is divided into $N$ layers of elementary thickness $\Delta x=L / N$ with :

$$
i=1+x \cdot \frac{N}{L}
$$

(i.e.: $i=1$ if $x=0$ and $i=N+1$ if $x=L$ ).

The diffusion terms are thus approximated by differences: 


$$
\frac{\partial[X]}{\partial t}=D_{X} \cdot \frac{[X]_{i+1}-2 \cdot[X]_{i}+[X]_{i-1}}{(\Delta x)^{2}}
$$

$\mathrm{X}$ being a mobile species, i.e. $\mathrm{AH}$ or $\mathrm{O}_{2}$.

$\Delta x$ was fixed equal to $10 \mu \mathrm{m}$.

$D_{A H}$ and $D_{02}$ were fixed from literature data:

$D_{02}=0.44 \times 10^{-4} \times \exp (-4400 / T) \mathrm{m}^{2} \mathrm{~s}^{-1}$ (Van Krevelen and Te Nijenhuis, 2009),

$D_{A H}=0.025 \times \exp (-8195 / T) m^{2} s^{-1}$ adapted from Oral et al. (2006) for vitamin $E$,

$D_{A H}=2.1 \times 10^{3} \times \exp (-12551 / T) \mathrm{m}^{2} \mathrm{~s}^{-1}$ adapted from Roe et al. (1974), Moisan (1980), Limm and Hollifield (1996) for AO1,

$D_{A H}=0.69 \times \exp (-8804 / T) m^{2} s^{-1}$ from Moisan (1980) for AO2.

This differential system is numerically solved in time and space (Rincon et al., 2001) using a commercial solver (namely the function ODE23s of Matlab ${ }^{\circledR}$ ) specifically designed for stiff problems. Let us precise that it is solved in amorphous phase.

The boundary conditions are:

- at $\mathrm{t}=0, \forall \mathrm{x},\left[\mathrm{P}^{\circ}\right]_{0}=\left[\mathrm{POO}^{\circ}\right]_{0}=\left[\mathrm{PO}{ }^{\circ} \mathrm{OP}\right]_{\text {cage }}=0,[\mathrm{PH}]_{0}=60 \mathrm{~mol} \mathrm{l}^{-1},[\mathrm{POOH}]_{0}=10^{-4} \mathrm{~mol} \mathrm{l}^{-1}$ (apart for simulations in Figure 9 were $[\mathrm{POOH}]_{0}$ was considered as an adjustable parameter expressing the level of unstable moiety in several PE from different sources).

- $[A H]_{0}$ is calculated from stabilizer molar mass $M_{A H}$, functionality $f_{A H}$ (i.e. number of phenol groups by molecule), weight ratio $\mathrm{w}_{\mathrm{AH}}$ and polymer crystalline ratio $\mathrm{x}_{\mathrm{C}}$ and density $\rho_{\mathrm{PE}}$ :

$$
[\mathrm{AH}]=\frac{1}{1-\mathrm{x}_{\mathrm{C}}} \cdot \frac{\rho_{\mathrm{PE}}}{\mathrm{M}_{\mathrm{AH}}} \cdot \mathrm{f}_{\mathrm{AH}} \cdot \mathrm{w}_{\mathrm{AH}}
$$

- at $\mathrm{t}=0, \forall \mathrm{x}$, and at $\mathrm{x}=0$ and $\mathrm{x}=\mathrm{L}$ ( $\mathrm{L}$ being the thickness of the sample), $\forall \mathrm{t},\left[\mathrm{O}_{2}\right]=\mathrm{s}_{\mathrm{O} 2} \times \mathrm{P}_{\mathrm{O} 2}$ with $\mathrm{s}_{\mathrm{O} 2} \sim$ $1.8 \times 10^{-8} \mathrm{~mol} \mathrm{I}^{-1} \mathrm{~Pa}^{-1}$ (Van Krevelen and Te Nijenhuis, 2009). 
From the numerical solution of differential system, the model predicts the changes of reactive species concentrations such as $\left[\mathrm{P}^{\circ}\right](\mathrm{x}, \mathrm{t}),\left[\mathrm{POO}^{\circ}\right](\mathrm{x}, \mathrm{t}),\left[\mathrm{PO}{ }^{\circ} \mathrm{OP}\right]_{\text {cage }}(\mathrm{x}, \mathrm{t}),[\mathrm{POOH}](\mathrm{x}, \mathrm{t}),[\mathrm{AH}](\mathrm{x}, \mathrm{t}),\left[\mathrm{A}^{\circ}\right](\mathrm{x}, \mathrm{t})$ that can be directly compared to experimental results after having corrected them with crystallinity by multiplying by $1-x_{C}$ term. Stable products (carbonyls, chain scissions, crosslink, double bonds) build up can also be predicted as post treatment data of the model, by combining reactive species concentration with rate constants given in Table 1 and yields given in Table 2). One has for example in the case of carbonyls:

$$
\frac{d[P=O]}{d t}=\left(1-x_{C}\right) \cdot\left(k_{1 u}[P O O H]+k_{1 b}[P O O H]^{2}+k_{62}\left[P O^{\circ} O P\right]_{\text {cage }}+2 k_{63}\left[P O^{\circ} O P\right]_{\text {cage }}\right)
$$

that can be compared with experimental results.

Since the system is solved in time and space. In the aim of comparisons with experimental results, values from simulations (in time and space) can be averaged :

$$
c(t)=\frac{1}{N+1} \cdot \sum_{i=1}^{N+1} c_{i}(t)
$$




\section{REFERENCES}

Allen, N.S., Chirinis-Padron, A., Henman, T.J., 1985. The photo-stabilisation of polypropylene: a review. Polym Degrad. Stab. 13, 31-76.

Al-Malaika, S., Goonetileka, M.D.R.J., Scott, G., 1991. Migration of 4-substituted 2-hydroxy benzophenones in low density polyethylene: Part I-Diffusion characteristics. Polym. Degrad. Stab. 32, 231-247.

Al-Malaika, S., Issenhuth, S., Burdick, D., 2001. The antioxidant role of vitamin E in polymers V. Separation of stereoisomers and characterisation of other oxidation products of $\mathrm{dl}$ - $\alpha$-tocopherol formed in polyolefins during melt processing. Polym. Degrad. Stab. 73, 491-503.

Al-Malaika, S., Peng. X., 2008. Stabilisation of metallocene ethylene-1-octene copolymers during multiple extrusions. Polym. Degrad. Stab. 93, 1619-1631.

Amorati, R., Fumo, M.G., Menichetti, S., Mugnaini, V., Pedulli, G.F., 2006. Electronic and hydrogen bonding effects on the chain-breaking activity of sulfur-containing phenolic antioxidants. J. Org. Chem. 71, 6325-6332.

Amorati, R., Cavalli, A., Fumo, M.G., Masetti, M., Menichetti, S., Pagliuca, C., Pedulli, G.F. , Viglianisi, C., 2007. Kinetic and thermochemical study of the antioxidant activity of sulfur-containing analogues of vitamin $E$. Chem.- Eur. J. 13, 8223-8230.

Billingham, N.C., Calvert, P.D., Okopi, I.W., Uzuner, A., 1991. The solubility of stabilizing additives in polypropylene. Polym. Degrad. Stab. 31, 23-36.

Bracco, P., Brunella, V., Zanetti, M., Luda, M.P., Costa, L., 2007. Stabilisation of ultra-high molecular weight polyethylene with Vitamin E. Polym. Degrad. Stab. 92, 2155-2162.

Breese, K.D., Lamèthe, J.-F., DeArmitt, C., 2000. Improving synthetic hindered phenol antioxidants: learning from vitamin E. Polym. Degrad. Stab. 70, 89-96.

Calvert, P.D., Billingham, N.C., 1979. Loss of additives from polymers: A theoretical model. J. Appl. Polym. Sci. 24, 357-370.

Clough, R.L., Gillen, K.T., 1990. Stabilizer additives in ionizing radiation environments under oxidizing conditions. Polym. Degrad. Stab. 30, 309-317.

Costa, L., Carpentieri, I., Bracco, P. 2008. Post electron-beam irradiation oxidation of orthopaedic UHMWPE. Polym. Degrad. Stab. 93, 1695-1703.

Costa, L., Carpentieri, I. Bracco, P., 2009. Post electron-beam irradiation oxidation of orthopaedic Ultra-High Molecular Weight Polyethylene (UHMWPE) stabilized with vitamin E. Polym. Degrad. Stab. 94, 1542-1547.

Denisov, E.T., Afanas'Ev, I.B., 2005. Oxidation and Antioxidants in Organic Chemistry and Biology. CBC Taylor \& Francis Group Boca Raton, London, New York, Singapore. pp. 491-540.

Fu, J., Doshi, B.N., Oral, E., Muratoglu, O.K., 2013. High temperature melted, radiation cross-linked, vitamin E stabilized oxidation resistant UHMWPE with low wear and high impact strength. Polymer 54, 199-209.

Gillen, K.T., Clough, R.L., (1981). Occurence and implications of radiation dose-rate effects for material aging studies. Rad. Phys. Chem. (1977) 18, 679-687.

Gillen, K.T., Clough, R.L., 1992. Rigorous experimental confirmation of a theoretical model for diffusion-limited oxidation. Polymer 33, 4358-4365. 
Jahan, M.S., Walters, B.M., 2011. Macroradical reaction in ultra-high molecular weight polyethylene in the presence of vitamin E. Rad. Phys. Chem. 80, 281-285.

Khelidj, N., Colin, X., Audouin, L., Verdu, J., 2005. A simplified approach for the lifetime prediction of PE in nuclear environments. Nucl. Instrum. Meth. B. 236, 88-94.

Khelidj, N., Colin, X., Audouin, L., Verdu, J., Monchy-Leroy, C., Prunier, V., 2006. Oxidation of polyethylene under irradiation at low temperature and low dose rate. Part II. Low temperature thermal oxidation. Polym. Degrad. Stab. 91, 1598-1605.

Latocha, C., Uhniat, M. 1992. The kinetics of oxidative induction of LDPE stabilized with commercial antioxidants. Polym. Degrad. Stab. 35, 17-22.

Limm, W., Hollifield, H.C., 1993. Modelling of additive diffusion in polyolefins. Food Addit. Contam. 13, 949-967.

Lucarini, M., Pedulli, G.F., 2007. Overview of Antioxidant Activity of Vitamin E, in: Preedy, V.R., Watson, R.R. (Eds.), The Encyclopedia of Vitamin E. CAB International, Oxon, pp. 3-10.

Mallégol, J., Carlsson, D.J., Deschênes, L., 2001. Post- $\psi$-irradiation reactions in vitamin E stabilised and unstabilised HDPE. Nucl. Instrum. Meth. B. 185, 283-293.

Mallégol, J., Carlsson, D.J., Deschênes, L., 2001. Antioxidant effectiveness of vitamin E in HDPE and tetradecane at $32^{\circ} \mathrm{C}$. Polym. Degrad. Stab. $73,269-280$.

Mallégol, J., Carlsson, D.J., Deschênes, L., 2001. A comparison of phenolic antioxidant performance in HDPE at 32-80 C. Polym. Degrad. Stab. 73, 259-267.

Miller, F.A., Fateley, W.G., Witkowski, R.E., 1967. Torsional frequencies in the far infrared-V. Torsions around the $\mathrm{C}-\mathrm{C}$ single bond in some benzaldehydes, furfural, and related compounds. Spectrochim. Acta A. 23, 891908.

Moisan, J.Y., 1980. Diffusion des additifs du polyethylene-I: Influence de la nature du diffusant. Eur. Polym. J. 16, 979-987.

Øgaard Madsen, J., Berg Olsen, N., Atlung, G., 1985. Effectiveness of antioxidants: Suppression of evolution of gaseous degradation products from low-density polyethylene during thermo-oxidation. Polym. Degrad. Stab. $12,131-140$.

Oral, E., Greenbaum, E.S., Malhi, A.S., Harris, W.H., Muratoglu, O.K., 2005. Characterization of irradiated blends of image-tocopherol and UHMWPE. Biomaterials 26, 6657-6663.

Oral, E., Wannomae, K.K., Rowell, S.L., Muratoglu, O.K., 2006. Migration stability of $\alpha$-tocopherol in irradiated UHMWPE. Biomaterials 27, 2434-2439.

Oral, E., Wannomae, K.K., Rowell, S.L., Muratoglu, O.K., 2007. Diffusion of vitamin E in ultra-high molecular weight polyethylene. Biomaterials 28, 5225-5237.

Oral, E., Godleski Beckos, C., Malhi, A.S., Muratoglu, O.K., 2008. The effects of high dose irradiation on the cross-linking of vitamin E-blended ultrahigh molecular weight polyethylene. Biomaterials 29, 3557-3560.

Peña, J.M., Allen, N.S., Edge, M., Liauw, C.M., Valange, B., 2001. Interactions between carbon black and stabilisers in LDPE thermal oxidation. Polym. Degrad. Stab. 72, 163-174.

Pospíšil, J., 1991. The key role of antioxidant transformation products in the stabilization mechanisms-a critical analysis. Polym. Degrad. Stab. 34, 85-109. 
Pospíšil, J., 1993. Chemical and photochemical behaviour of phenolic antioxidants in polymer stabilization: a state of the art report, part II. Polym. Degrad. Stab. 39, 103-115.

Pospíšil, J., Nešpůrek, S., Zweifel, H., 1996. The role of quinone methides in thermostabilization of hydrocarbon polymers-I. Formation and reactivity of quinone methides. Polym. Degrad. Stab. 54, 7-14.

Pospíšil, J., Habicher, W.-D., Pilař, J., Nešpůrek, S., Kuthan, J., Piringer, G.-O., Zweifel, H., 2002. Discoloration of polymers by phenolic antioxidants. Polym. Degrad. Stab. 77, 531-538.

Reiter, E., Jiang, Q., Christen, S., 2007. Anti-inflammatory properties of $\alpha$ - and $\gamma$-tocopherol. Mol. Aspects Med. 28, 668-691.

Richaud, E., Farcas, F., Fayolle, B., Audouin, L., Verdu, J., 2008. Accelerated ageing of polypropylene stabilized by phenolic antioxidants under high oxygen pressure. J. Appl. Polym. Sci. 110, 3313-3321.

Richaud, E., Monchy-Leroy, C., Colin, X., Audouin, L., Verdu, J., 2009. Kinetic modelling of stabilization coupled with stabilizer loss by evaporation. Case of dithioester stabilized polyethylene. Polym. Degrad. Stab. 94, 20042014.

Richaud, E., Fayolle, B., Verdu, J., 2011. Polypropylene stabilization by hindered phenols - Kinetic aspects. Polym. Degrad. Stab. 96, 1-11.

Richaud, E., 2013. Kinetic modelling of phenols consumption during polyethylene thermal oxidation. Eur. Pol. J. 49, 2223-2232.

Rincon-Rubio, L.M., Fayolle, B., Audouin, L., Verdu, J., 2001. A general solution of the closed-loop kinetic scheme for the thermal oxidation of polypropylene. Polym. Degrad. Stab. 74, 177-188.

Roe, R.-J., Bair, H.E., Gieniewski, C., 1974. Solubility and diffusion coefficient of antioxidants in polyethylene. J. Appl. Polym. Sci. 18, 843-856.

Schwarzenbach, K., Gilg, B., Muller, D., Knobloch, G., Pauquet, J.R., Rota Graziosi, P., Schmitter, A., Zingg, J., Kramer, E. 2001. Antioxidants, in: Zweifel, H. (Ed.), Plastics Additives Handbook, fifth ed. Hanser Gardner Publications, Cincinnati, pp. 1-139.

Tahan, G., Aytac, E. Aytekin, H., Gunduz, F., Dogusoy, G., Aydin, S., Tahan, V., Uzun, H., 2011. Vitamin e has a dual effect of anti-inflammatory and antioxidant activities in acetic acid-induced ulcerative colitis in rats. Can. J. Surg. 54, 333-338.

Van Krevelen, D.W., Te Nijenhuis, K., 2009. Properties of Polymers. Their Correlation with Chemical Structure; their Numerical Estimation and Prediction from Additive Group Contributions, fourth edition. Elsevier, Amsterdam. pp. 655-702. 